Maurer School of Law: Indiana University

Digital Repository@ Maurer Law

Indiana Law Journal

Volume 90 | Issue 3

Article 8

Summer 2015

\title{
Superstatute Theory and Administrative Common Law
}

Kathryn E. Kovacs

Rutgers University - Camden, kathryn.kovacs@rutgers.edu

Follow this and additional works at: https://www.repository.law.indiana.edu/ilj

Part of the Administrative Law Commons, Common Law Commons, and the Legislation Commons

\section{Recommended Citation}

Kovacs, Kathryn E. (2015) "Superstatute Theory and Administrative Common Law," Indiana Law Journal: Vol. 90 : Iss. 3 , Article 8.

Available at: https://www.repository.law.indiana.edu/ilj/vol90/iss3/8

This Article is brought to you for free and open access by the Law School Journals at Digital Repository @ Maurer Law. It has been accepted for inclusion in Indiana Law Journal by an authorized editor of Digital Repository @ Maurer Law. For more information, please contact rvaughan@indiana.edu.

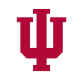

JEROME HALL LAW LIBRARY

INDIANA UNIVERSITY

Maurer School of Law
Bloomington 


\title{
Superstatute Theory and Administrative Common Law
}

\begin{abstract}
KATHRYN E. KOVACS*
This Article employs William Eskridge and John Ferejohn's theory of superstatutes as a tool to argue that administrative common law that contradicts or ignores the Administrative Procedure Act (APA) is illegitimate. Eskridge and Ferejohn conceive of statutes that emerge from a lengthy, public debate and take on great normative weight over time as "superstatutes." Superstatute theory highlights the deficiency in deliberation about the meaning of the APA. The APA bears all the hallmarks of a superstatute. Unlike the typical federal superstatute, however, the APA is not administered by a single agency. Thus, to respect and encourage the civic-republican style of deliberation that Eskridge and Ferejohn espouse, courts must adhere more closely to the compromises encoded in the statute's text, paying particular attention to the context and history of each individual provision. Courts should hesitate before moving too far towards the boundaries of the text's possible meaning. Venturing beyond those boundaries altogether is even more troubling. In the absence of an agency that spurs public deliberation about the meaning of the APA, administrative common law that contradicts or ignores the APA should be presumed to be illegitimate.
\end{abstract}

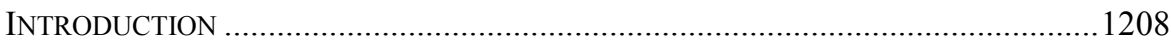

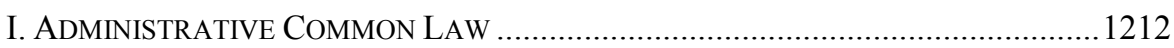

II. ESKRIDGE AND FEREJOHN'S THEORY OF SUPERSTATUTES ...............................1218

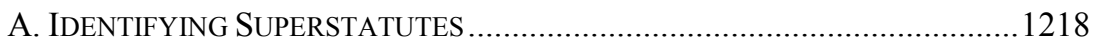

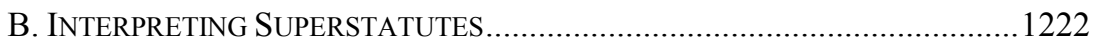

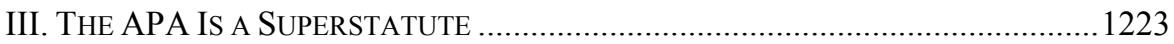

A. EMERGED FROM A LONG PERIOD OF DELIBERATION ...............................1224

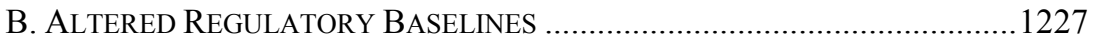

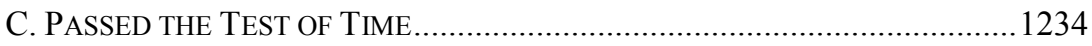

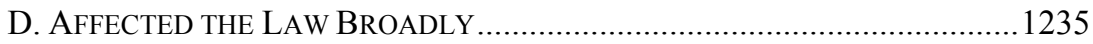

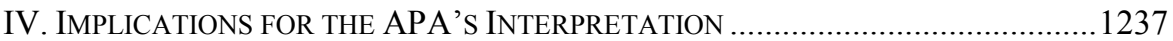

A. THE RoLE OF DELIBERATION IN SUPERSTATUTE THEORY .......................1237

B. THE LACK OF AgENCY-CENTEREd DELIBERATION IN THE APA.............1242

C. DELIBERATION-FOCUSED REVIEW OF THE APA ………..........................1248

D. ADMINISTRATIVE COMMON LAW'S WEAKNESS .....................................1254

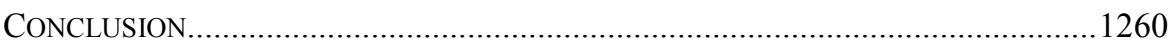

* Associate Professor, Rutgers School of Law. I owe a debt of gratitude to Bill Eskridge, John Ferejohn, Emily Hammond, Linda Jellum, Gillian Metzger, John Oberdiek, Craig Oren, Richard Seamon, Asher Steinberg, Peter Strauss, Chris Walker, Kathryn Watts, Bob Williams, and workshop participants at American University Washington College of Law, Fordham Law School, Rutgers School of Law, the University of Kentucky College of Law, and the University of Denver Sturm College of Law. 


\section{INTRODUCTION}

The Administrative Procedure Act of 1946 (APA or the "Act") 1 is one of the most important statutes in the United States Code. The Constitution assumes that administrative agencies will assist the President in fulfilling his executive duties, but it says nothing about agencies' structures and functions or about their relationships with the other branches of government. ${ }^{2}$ After the explosion in the number of federal agencies in the early twentieth century, ${ }^{3}$ Congress stepped into the breach, setting forth basic principles of agency procedure and judicial review in the APA. The APA has taken on quasi-constitutional status. ${ }^{4}$ Although agency-specific statutes now abound, the APA is still the "fundamental charter" of the "Fourth Branch" of the government. ${ }^{5}$

Administrative common law is at the heart of one of the oldest debates about the APA. Congress worked for years to pass the Act. ${ }^{6}$ It represented a monumental compromise between conservatives and liberals, and neither side was fully satisfied. Following its enactment, both sides set out to convince the courts that their view of the new law was the right view. Conservatives sold the law as imposing important new restrictions on agencies, while liberals viewed the law as simply restating preexisting common law. ${ }^{7}$ By and large, the liberals won. Traditionally, the APA is viewed as leaving ample room for the courts to continue to apply and develop administrative common law, or at least to read the Act's terms loosely. ${ }^{8}$ That interpretation of the APA, however, does not respect the enormous effort that went

1. Pub. L. No. 79-404, 60 Stat. 237 (codified as amended at 5 U.S.C. $\S \S 551-706$ (2012)).

2. See Steven G. Calabresi \& Gary Lawson, The Unitary Executive, Jurisdiction Stripping, and the Hamdan Opinions: A Textualist Response to Justice Scalia, 107 ColuM. L. REV. 1002, 1010 (2007); William N. Eskridge, Jr. \& John Ferejohn, Constitutional Horticulture: Deliberation-Respecting Judicial Review, 87 TEX. L. REV. 1273, 1281-82 (2009) [hereinafter Eskridge and Ferejohn, Constitutional Horticulture]; Peter L. Strauss, The Place of Agencies in Government: Separation of Powers and the Fourth Branch, 84 CoLuM. L. REV. 573, 576-77 (1984).

3. In the first thirty years of the twentieth century, the number of federal administrative agencies doubled. George B. Shepherd, Fierce Compromise: The Administrative Procedure Act Emerges from New Deal Politics, 90 Nw. U. L. REV. 1557, 1561 (1996).

4. See Bruce Ackerman, The Emergency Constitution, 113 YALE L.J. 1029, 1077 (2004); William R. Andersen, Chevron in the States: An Assessment and a Proposal, 58 Admin. L. REV. 1017, 1033 (2006); Michael Asimow, The Spreading Umbrella: Extending the APA's Adjudication Provisions to All Evidentiary Hearings Required by Statute, 56 ADMIN. L. REV. 1003, 1004 (2004); Jerry L. Mashaw, Federal Administration and Administrative Law in the Gilded Age, 119 YALE L. J. 1362, 1365 (2010); Thomas W. Merrill, Capture Theory and the Courts: 1967-1983, 72 ChI.-Kent L. ReV. 1039, 1039 (1997).

5. Jack M. Beermann \& Gary Lawson, Reprocessing Vermont Yankee, 75 GEO. WASH. L. REV. 856, 874 (2007).

6. Shepherd, supra note 3.

7. Id. at $1662-66$.

8. See Kenneth Culp Davis, Administrative Law Treatise $\S \S 2.17,2.18,6.37,7.19$, 14.10 (2d ed. 1978) [hereinafter DAVis, AdMinistrative LAW TrEatise] (asserting that the courts do and should continue to develop administrative common law); LOUIS L. JAFFE, Judicial CONTROL OF ADMINISTRATIVE ACTION 327-29, 336-37, 372 (1965) (asserting that the APA has had little effect on the common law of judicial review). 
into constructing this unique enactment, much less the significant attention Congress has paid to the APA since its enactment. Nor does it pay heed to the need for open, public deliberation in a functioning democracy.

In this Article, I view the APA through the lens of an important new theory of statutory interpretation: William Eskridge and John Ferejohn's theory of superstatutes. ${ }^{9}$ Superstatute theory highlights the deficiency in deliberation about the meaning of the APA. That deliberation deficiency makes it problematic for courts to interpret the APA's terms loosely, much less create law that exceeds those terms altogether and contravenes Congress's intent. Any interpretation of the APA should focus on the language of each individual provision, as well as its context and history, both before and after enactment. In the very least, courts should not ignore the APA.

Professors Eskridge and Ferejohn employ the term "superstatute" to refer to statutes that have become "entrenched" in America's statutory constitution. ${ }^{10}$ They are enacted "after lengthy normative debate" and "prove robust as a solution, a standard, or a norm over time." 11 Although Eskridge and Ferejohn did not identify the APA as a superstatute, the Act exemplifies this idea: it resulted from years of legislative activity and has become deeply entrenched.

There is a general consensus that the APA is not a typical statute. Then-Professor Scalia observed in 1978 that "the Supreme Court regarded the APA as a sort of superstatute, or subconstitution, in the field of administrative process: a basic framework that was not lightly to be supplanted or embellished." 12 Other

9. See generally William N. Eskridge, Jr. \& John Ferejohn, A Republic of Statutes: The New American Constitution (2010) [hereinafter Eskridge \& Ferejohn, Republic]; William N. Eskridge, Jr. \& John Ferejohn, Super-Statutes, 50 DukE L.J. 1215 (2000) [hereinafter Eskridge \& Ferejohn, Super-Statutes]; William N. Eskridge, Jr., America's Statutory “constitution,” 41 U.C. DAVIS L. REV. 1 (2007) [hereinafter Eskridge, America's Statutory "constitution"]. Eskridge and Ferejohn's work has contributed significantly to the development of legal theory. See, e.g., Paul Frymer, Statutes, Courts, and Democracy in America, 47 TulSA L. REV. 229, 234 (2011) (book review) ("vast, ambitious, intellectually provocative, and declarative"); Leslie Gielow Jacobs, Growing a Constitution, 27 Const. Comment. 647, 654 (2011) (book review) ("inspiring"); Robert A. Katzmann, Introduction to The Yale Law Journal Online Symposium on Eskridge and Ferejohn's A Republic of Statutes: The New American Constitution, 120 YALE L.J. ONLINE 293, 293 (2011), http://www.yalelawjournal.org/forum /introduction-to-the-yale-law-journal-online-symposium-on-eskridge-and-ferejohns-a-republic -of-statutes-the-new-american-constitution ("landmark collaboration"); Mathew D. McCubbins \& Daniel B. Rodriguez, Superstatutory Entrenchment: A Positive and Normative Interrogatory, 120 YALE L. J. ONLINE 387, 406 (2011), http://www.yalelawjournal.org/forum/superstaturoty -entenchment-a-positive-and-normative-interrogatory ("an admirable - indeed historic - effort at big-picture legal theory"); Edward L. Rubin, How Statutes Interpret the Constitution, 120 YALE L.J. ONLINE 297, 298 (2011), http://www.yalelawjournal.org/forum/how-statutes-interpret -the-constitution ("a major contribution"); Glen Staszewski, Constitutional Dialogue in a Republic of Statutes, 2010 Mich. ST. L. REV. 837, 862 (“important”).

10. ESKRIDGE \& FEREJOHN, REPUBLIC, supra note 9, at 111.

11. Eskridge \& Ferejohn, Super-Statutes, supra note 9, at 1216. Eskridge and Ferejohn abandoned the hyphen in "super-statutes" in their recent book. See ESKRIDGE \& FEREJOHN, REPUBLIC, supra note 9.

12. Antonin Scalia, Vermont Yankee: The APA, the D.C. Circuit, and the Supreme Court, 1978 Sup. Cт. REV. 345, 363. 
commentators agree that the APA has taken on quasi-constitutional status. ${ }^{13}$ Some have even dubbed the APA a superstatute under Eskridge and Ferejohn's theory. ${ }^{14}$ None, however, has taken on the task of demonstrating why the APA is a superstatute; nor have scholars explored the implications of that status.

Eskridge and Ferejohn posit that superstatutes are and should be interpreted dynamically and evolutively to grow and change over time. ${ }^{15}$ Hence, one might assume that dubbing the APA a superstatute would lend support to the scholars who applaud the courts' continued development of administrative common law. ${ }^{16}$ Applying superstatute theory to the APA, however, yields a surprising result because the APA differs from most other federal superstatutes in one important respect: no single agency is charged with its implementation. Single-agency implementation is not a requirement for superstatute status, ${ }^{17}$ but it is central to the assertion that superstatutes should be interpreted broadly and evolutively. That assertion is built on a civic-republican model of deliberation that necessitates public involvement in legal change. In the absence of direct public engagement through an election, Eskridge and Ferejohn's model of deliberation puts a single agency at the center of an interpretive web, with the other branches of government and the public intertwined. Unlike most other superstatutes, however, agencies are not the primary interpreters of the APA - courts are. And courts are not deliberative in the civic-republican sense that superstatute theory demands to legitimize evolutive interpretation. ${ }^{18}$

13. See supra note 4.

14. E.g., Richard Albert, Nonconstitutional Amendments, 22 CAN. J. L. \& JuRIS. 5, 18 (2009); Eric Berger, Individual Rights, Judicial Deference, and Administrative Law Norms in Constitutional Decision Making, 91 B.U. L. REV. 2029, 2054 (2011); Frymer, supra note 9, at 234; David S. Law, Generic Constitutional Law, 89 MinN. L. REV. 652, 675-76 (2005); John C. Roberts \& Erwin Chemerinsky, Entrenchment of Ordinary Legislation: A Reply to Professors Posner and Vermeule, 91 Calif. L. Rev. 1773, 1816 n.151 (2003); Cass R. Sunstein \& Adrian Vermeule, Libertarian Administrative Law, 81 U. CHI. L. REV. 393, 466 (2015); see also Lawrence Solum, Gluck on Entrenched Canons of Statutory Interpretation, LEgAL THEORY Blog (April 1, 2013, 12:15 p.m.), http://lsolum.typepad.com/legaltheory /2013/04/gluck-on-entrenched-canons-of-statutory-interpretation.html.

15. EsKridge \& FEREJOHn, Republic, supra note 9, at 291, 293; Eskridge \& Ferejohn, Super-Statutes, supra note 9, at 1247, 1249.

16. E.g., Davis, Administrative Law Treatise, supra note 8 , at $\S \S 2.17,2.18,6.37$, 7.19, 14.10; Kenneth Culp Davis, Administrative Common Law and the Vermont Yankee Opinion, 1980 Utah L. Rev. 3, 3 [hereinafter Davis, Administrative Common Law]; JAFFe, supra note 8, at 327-29, 336-37, 372, 376; Gillian E. Metzger, Annual Review of Administrative Law-Foreword: Embracing Administrative Common Law, 80 GEO. WASH. L. REV. 1293, 1293 (2012); Scalia, supra note 12, at 382, 385-87; see also Emily S. Bremer, The Unwritten Administrative Constitution, 66 FLA. L. REV. 1215, 1246 (2014) (stating that the scholarly literature "increasingly embraces the validity of administrative common law"). But see John F. Duffy, Administrative Common Law in Judicial Review, 77 TeX. L. REV. 113, 115 (1998).

17. Eskridge and Ferejohn include "executive-legislative partnerships," state statutes that reflect a consensus among states, and international agreements within the ambit of “superstatutes." ESKRIDGE \& FEREJOHN, REPUBLIC, supra note 9, at 7, 16, 212-13.

18. In asserting the normative superiority of deliberation that involves not just the parties to a particular court proceeding but the public and representative branches of government, Eskridge and Ferejohn join a long line of theorists, including Jeremy Waldron, Amy Gutmann, Dennis Thompson, and Mark Seidenfeld. See infra Part IV.A. 
Eskridge and Ferejohn did not address superstatutes like the APA that are entrenched and quasi-constitutional but do not undergo the sort of civic-republican deliberation their theory requires to justify evolutive interpretation. I apply superstatute theory to this new category to discern how the APA should be interpreted..$^{19}$ Eskridge and Ferejohn posit that judicial review of superstatutes should respect and encourage public deliberation. In the APA's case, that means the courts should adhere more closely to the compromises encoded in the statute's text and hesitate before moving too far towards the boundaries of the text's possible meaning. Given the extraordinary legislative process that led to the APA's enactment and the relative paucity of agency-based deliberative feedback since then, courts should be particularly chary of interpreting the APA's text in a way that shifts the balance Congress reached through the political process. Courts should look more closely at the context and history of the APA's individual provisions, including Congress's treatment of each provision in the original legislative process and the quality of deliberation the provision has seen since enactment.

If moving too far towards the boundaries of the APA's text is problematic, then venturing beyond those boundaries altogether is even more troubling. The line between broad, evolutive interpretation of the APA and administrative common law is blurry, but there are many doctrines of administrative law that cross the line. ${ }^{20} \mathrm{My}$ concern here is with those doctrines of administrative common law that contravene or simply ignore the APA, such as doctrines that give superdeference to certain agencies despite Congress's deliberate decision to subject all agencies to the same standard of review; procedural requirements that exceed the APA's minimal rulemaking provisions; and prudential ripeness doctrine, which conflicts with the APA's promise of judicial review to any person who suffers a legal wrong and challenges final agency action. ${ }^{21}$ Scholars have long defended the courts' journeys into the realm of administrative common law. ${ }^{22}$ Applying superstatute theory to the APA highlights a weakness in their defense. In the absence of deliberation that involves the public, administrative common law that ignores or contravenes the APA must be presumed to be illegitimate. ${ }^{23}$

In Part I, I provide a brief introduction to administrative common law, and in Part II, I do the same for superstatute theory. In Part III, I demonstrate that the APA is a superstatute. Finally, in Part IV, I show that, although it is entrenched, the APA does not undergo the civic-republican style of deliberation that superstatute theory requires to justify evolutive interpretation. Although Eskridge and Ferejohn did not address this category of superstatutes, their theory nonetheless provides insight about

19. Whether any other superstatutes fall into this category is a subject for future inquiry.

20. See infra Part I.

21. Id.

22. See supra note 16.

23. Superstatutes theory has its critics. E.g., Frymer, supra note 9, at 234-37; McCubbins \& Rodriguez, supra note 9; Adrian Vermeule, Superstatutes, New RePUblic (Oct. 26, 2010), http://www.newrepublic.com/book/review/superstatutes (reviewing ESKRIDGE \& FEREJOHN, REPUBLIC, supra note 9). That criticism does not undercut my reliance on the theory since I use it merely as a launchpad for discussion. Moreover, critics of superstatute theory are perhaps more likely to be critics of dynamic interpretation and administrative common law and thus reach the same destination as I do by a different route. 
how the APA should be interpreted and leads to the conclusion that administrative common law that contradicts Congress's intent faces significant legitimacy problems.

\section{ADMINISTRATIVE COMMON LAW}

Despite the Supreme Court's pronouncement in Erie Railroad Co. v. Tompkins that "[t]here is no federal general common law," 24 federal common law persists. The Supreme Court has held that federal common law is permissible in a "few and restricted" areas "in which a federal rule of decision is necessary to protect uniquely federal interests, and those in which Congress has given the courts the power to develop substantive law." ${ }^{25}$ Recognizing Congress's "superior authority" in policy making and the judiciary's "place in the constitutional scheme," 26 however, federal courts exercise caution in developing common law, even where its creation is authorized, such as in admiralty law. ${ }^{27}$

Any attempt to discern where statutory interpretation ends and common law begins is challenging, since the two exist on a continuum. ${ }^{28}$ Like Gillian Metzger, I conceive of common law as judicial pronouncements that "venture too far afield from statutory text or discernible legislative purpose to count simply as statutory interpretation." ${ }^{29}$ A text may be subject to many interpretations, depending on the interpreter's approach. Common law exceeds the boundaries of any permissible interpretation. ${ }^{30}$ Thus, as John Duffy observed, "[T]he split between statutory and

24. 304 U.S. 64, 78 (1938); see also Gillian E. Metzger, Ordinary Administrative Law as Constitutional Common Law, 110 CoLuM. L. REV. 479, 512 (2010) ("[T] he Erie principle has not governed in anything near such absolute form ...."). As Abbe Gluck points out, "The Erie rule itself is a federal common law doctrine." Abbe R. Gluck, The Federal Common Law of Statutory Interpretation: Erie for the Age of Statutes, 54 WM. \& MARY L. REV. 753, 798, 811 (2013).

25. Tex. Indus., Inc. v. Radcliff Materials, Inc., 451 U.S. 630, 640 (1981) (citations and internal quotation marks omitted). How much room Erie leaves for federal common law is a matter of debate. See Gluck, supra note 24, at 809.

26. Miles v. Apex Marine Corp., 498 U.S. 19, 27, 32 (1990).

27. See Thomas Field, Craig Allen Nard \& John Duffy, Dickinson v. Zurko: An Amicus Brief, 4 Marq. Intell. Prop. L. Rev. 49, 71 (2000).

28. Erwin Chemerinsky, Federal Jurisdiction $\S$ 6.1, at 367 (5th ed. 2007); Davis, Administrative Common Law, supra note 16, at 4; Metzger, supra note 16, at 1310-11.

29. Metzger, supra note 16, at 1295; see also Davis, Administrative Common Law, supra note 16, at 3 ("Common law is law that courts have created without interpreting a constitutional or statutory provision."); $c f$. Thomas W. Merrill, The Common Law Powers of Federal Courts, 52 U. CHI. L. REV. 1, 5 (1985) (defining "federal common law" as "any federal rule of decision that is not mandated on the face of some authoritative federal text-whether or not that rule can be described as the product of 'interpretation' in either a conventional or unconventional sense" (emphasis in original)). Others have used the term "administrative common law" to refer to "agency-developed interpretations of law." Richard W. Murphy, Hunters for Administrative Common Law, 58 Admin. L. Rev. 917, 920 n.16 (2006).

30. See Jack M. Beermann, Common Law and Statute Law in Administrative Law, 63 ADMIN. L. REV. 1, 3 (2011) (arguing that common law reflects "a degree of creativity beyond that expected of a court engaged in the construction and application of an authoritative text"); Duffy, supra note 16, at 115 ("Under the common-law method, a court decides a case without 
common-law approaches in administrative law" is not a "disagreement[] about how to interpret the APA, but whether to interpret the APA." 31

Administrative law is infused with common law. ${ }^{32}$ Some provisions of the APA carve out space for common law, like the savings clause that permits the courts to continue to employ equitable doctrines in fashioning remedies. ${ }^{33}$ But the Act does not delegate broad authority to the courts to develop administrative common law. Section 559 of the APA provides that the Act does not "limit or repeal additional requirements imposed by statute or otherwise recognized by law." ${ }^{34}$ The Supreme Court held in Dickinson v. Zurko that section 559 did not preserve the courts' ability to continue to fashion administrative common law, but merely "grandfathered common-law variations" that were clearly established when the APA was enacted. ${ }^{35}$

Some provisions of the APA leave room for, and indeed are so indefinite as to invite, judicial elaboration. The terms "arbitrary" and "capricious" in section 706's standard of review, for example, might provide a springboard for requiring agencies to evaluate "relevant data" and disregard factors that Congress did not intend for the agency to consider. ${ }^{36}$ Other provisions are more definite. Section 704 requires exhaustion of administrative remedies "only when expressly required by statute or when an agency rule requires appeal before review and the administrative action is made inoperative pending that review." ${ }^{37}$

My concern is with common law that contradicts or ignores the APA. ${ }^{38}$ Several examples will help to frame my argument. I have previously demonstrated that in the

guidance from any textual codification of law and policy.").

31. Duffy, supra note 16, at 181 (emphasis in original).

32. Davis, Administrative Common Law, supra note 16, at 3; Duffy, supra note 16, at 117; Metzger, supra note 16, at 1311; Metzger, supra note 24, at 508; Symposium, Present at the Creation: Regulatory Reform Before 1946, 38 ADMIN. L. REv. 511, 526 (1986) (Kenneth Culp Davis observing that the bulk of administrative law is common law). Professor Duffy explains some of the reasons for administrative common law's staying power. Duffy, supra note 16 , at $119,130-38$.

33. See 5 U.S.C. $\S 702$ (2012) ("Nothing herein . . affects . . the power or duty of the court to . . . deny relief on any other appropriate legal or equitable ground . . . ."); see also Duffy, supra note 16, at 128; Ronald M. Levin, "Vacation" at Sea: Judicial Remedies and Equitable Discretion in Administrative Law, 53 DukE L.J. 291 (2003).

34. 5 U.S.C. $\$ 559$ (2012).

35. 527 U.S. 150, 155, 161 (1999). Even the dissenting justices agreed with that interpretation of $\S 559$. Id. at 171 (Rehnquist, J., dissenting).

36. 5 U.S.C. $§ 706$ (2012); see Motor Vehicle Mfrs. Ass'n v. State Farm Mut. Auto. Ins. Co., 463 U.S. 29, 43 (1983); see also Beermann \& Lawson, supra note 5, at 882 ("Hard-look review may or may not be a correct or even plausible interpretation of $\S 706(2)(\mathrm{A})$."); Metzger, supra note 24, at 491 ("Over the years ... the courts came to read arbitrary and capricious in an increasingly rigorous fashion until it came to embody today's hard look review."); $c f$. Adrian Vermeule, Our Schmittian Administrative Law, 122 HARV. L. REV. 1095, 1118-21, 1134 (2009) (arguing that judicial review under the arbitrary or capricious standard can be adjusted to respond to emergency circumstances).

37. Darby v. Cisneros, 509 U.S. 137, 154 (1993) (emphasis in original) (discussing 5 U.S.C. § 704 (1992)).

38. See Kathryn E. Kovacs, Leveling the Deference Playing Field, 90 OR. L. REv. 583, 600-03 (2011) [hereinafter Kovacs, Leveling]; see also Am. Elec. Power Co. v. Connecticut, 
APA, Congress deliberately subjected all agencies to the same standard of reviewthe deferential arbitrary or capricious standard - and declined the War Department's request that the military be exempted from the bill altogether. ${ }^{39}$ Yet the courts give the military more deference than other agencies. ${ }^{40}$ Broad application of a commonlaw superdeference standard to the military is unjustified, because the APA's exception for "military authority exercised in the field in time of war" insulates core military functions from judicial review. ${ }^{41}$ That exception obviates separation-of-powers concerns with judicial review of military action, leaving only a common law rule that contradicts Congress's considered judgment. ${ }^{42}$

John Duffy showed that "ripeness doctrine has no place in the APA." 43 The APA provides that if a person is "suffering legal wrong" or is "adversely affected or aggrieved by agency action" and is challenging "final agency action for which there is no adequate remedy in a court," that person is entitled to judicial review. ${ }^{44}$ Prudential ripeness doctrine, in contrast, balances "the fitness of the issues for judicial decision and the hardship to the parties of withholding court consideration." 45 Although the Court recognized that the APA cabins exhaustion doctrine, ${ }^{46}$ it continues to apply common law ripeness doctrine even though, as Professor Duffy pointed out, "[T] he APA does not authorize balancing."

131 S. Ct. 2527, 2537 (2011) (explaining that the need for federal common law disappears when Congress enacts a statute addressing the question directly).

39. Kovacs, Leveling, supra note 38; Kathryn E. Kovacs, A History of the Military Authority Exception in the Administrative Procedure Act, 62 ADMIN. L. REV. 673, 697, 700-01 (2010) [hereinafter Kovacs, A History]. I employ the arbitrary or capricious standard as a catchall for the various standards set forth in $\S 706(2)$, as others have before me. See Indep. Acceptance Co. v. California, 204 F.3d 1247, 1248 n.1 (9th Cir. 2000); Ass'n of Data Processing Serv. Orgs., Inc. v. Bd. of Governors of the Fed. Reserve Sys., 745 F.2d 677, 683-84 (D.C. Cir. 1984); Beermann, supra note 30, at 24 ("The catchall standard that governs judicial review of agency action, which applies to most cases not involving formal agency adjudication, is the arbitrary and capricious test . . . ."); Emily Hammond Meazell, Super Deference, the Science Obsession, and Judicial Review as Translation of Agency Science, 109 Mich. L. REV. 733, 740 (2011) ("[S]ubsection (A) serves as a catch-all standard that generally applies . . . to review of informal adjudication and rulemaking."); Patricia M. Wald, Judicial Review in Midpassage: The Uneasy Partnership Between Courts and Agencies Plays On, 32 TulSA L.J. 221, 232 n.70, 233 (1996).

40. Kovacs, Leveling, supra note 38, at 591-99.

41. 5 U.S.C. $\S 551(1)(\mathrm{g})(2012)$.

42. Kovacs, Leveling, supra note 38, at 616-23. But see Abbe R. Gluck \& Lisa Schultz Bressman, Statutory Interpretation from the Inside-An Empirical Study of Congressional Drafting, Delegation, and the Canons: Part I, 65 StAn. L. Rev. 901, 1001-03 (2013) [hereinafter Gluck \& Bressman, Part I] (empirical study showing that congressional drafters may intend to delegate different levels of interpretive authority to different agencies); Lisa Schultz Bressman \& Abbe R. Gluck, Statutory Interpretation from the Inside-An Empirical Study of Congressional Drafting, Delegation, and the Canons: Part II, 66 StAN. L. ReV. 725, 753-54 (2014) [hereinafter Bressman \& Gluck, Part II] (discussing those results).

43. Duffy, supra note 16, at 162.

44. 5 U.S.C. $\$ \S 702,704$ (2012).

45. Abbott Labs. v. Gardner, 387 U.S. 136, 149 (1967).

46. Darby v. Cisneros, 509 U.S. 137, 154 (1993).

47. Duffy, supra note 16, at 177; see also Nat'1 Park Hospitality Ass'n v. Dep't of Interior, 
Nicholas Bagley recently demonstrated that the presumption in favor of judicial review of agency action is common law. ${ }^{48}$ The Supreme Court grounded that presumption in the APA's provisions authorizing any person "suffering legal wrong ... or adversely affected or aggrieved by agency action" to challenge "final agency action" in court. ${ }^{49}$ As Bagley pointed out, however, the APA only provides for judicial review "except to the extent that . . . statutes preclude judicial review." 50 Thus, the APA does not establish a presumption; it "establishes a default rule favoring judicial review where no statute precludes it." 51

Many scholars believe that Chevron doctrine ${ }^{52}$ is common law. ${ }^{53}$ The APA instructs that "the reviewing court shall decide all relevant questions of law." ${ }^{54}$ Yet, the Court in Chevron held that, if the relevant statute is silent or ambiguous on a question before the court, the court should defer to the administering agency's interpretation of the statute. ${ }^{55}$ In Chevron itself, the Court made no effort to reconcile its holding with the APA. Recently, the Court equated this part (step two) of the Chevron test with review under the APA's arbitrary or capricious standard, ${ }^{56}$ but it has yet to explain how that meshes with the instruction that courts decide questions of law. Justice Scalia may have come closest in his dissent in United States v. Mead Corp., where he suggested that, if a statute is ambiguous, the only remaining question of law is "whether the agency's interpretation had gone beyond the scope of discretion that the statutory ambiguity conferred." 57 Similarly, Chief Justice Roberts, in his dissent in City of Arlington v. FCC, opined that, in applying Chevron, the Court gives "binding deference to permissible agency interpretations of statutory ambiguities because Congress has delegated to the agency the authority to interpret those ambiguities 'with the force of law.' ... Whether Congress has conferred such

538 U.S. 803 (2003); Beermann, supra note 30, at 20 (citing Whitman v. Am. Trucking Ass'ns., 531 U.S. 457, 479 (2001)). The Supreme Court recently expressed some discomfort with prudential ripeness doctrine. See Susan B. Anthony List v. Driehaus, 134 S. Ct. 2334, 2347 (2014). The Court's discomfort, however, seems limited to evaluating ripeness as a question of jurisdiction. In Lexmark International, Inc. v. Static Control Components, Inc., the Court did not abandon the zone-of-interest test for prudential standing entirely, but merely shifted the analysis from jurisdiction to the merits. 134 S. Ct. 1377, 1387-90 (2014). The Court's citation of Lexmark in Susan B. Anthony List, 134 S. Ct. at 2347, indicates that the Court may be contemplating shifting the ripeness analysis to the merits but not abandoning it altogether.

48. Nicholas Bagley, The Puzzling Presumption of Reviewability, 127 HARV. L. REV. 1285, 1320-21 (2014).

49. Abbott Labs., 387 U.S. at 140 (citing 5 U.S.C. $\S \S 702,704$ (1964)).

50. Bagley, supra note 48, at 1304 (quoting 5 U.S.C. $\$ 701$ (a) (2012) (emphasis omitted)).

51. Id. at 1305.

52. Chevron USA, Inc. v. NRDC, 467 U.S. 837 (1984).

53. E.g., Beermann, supra note 30, at 21; Duffy, supra note 16, at 118, 189-99; Metzger, supra note 16, at 1300-01; see also Gluck, supra note 24, at 798, 801 (agreeing that Chevron is common law and arguing that other statutory interpretation tools are common law as well); Metzger, supra note 24, at 505-06 (characterizing Chevron as a "constitutionally inspired requirement[]" whose "constitutional underpinnings remain[] unspecified").

54. 5 U.S.C. $§ 706$ (2012).

55. Chevron, 467 U.S. at $842-45$.

56. Judulang v. Holder, 132 S. Ct. 476, 483 n.7 (2011).

57. 533 U.S. 218, 241 n.2 (2001) (Scalia, J., dissenting). 
power is the 'relevant question[ ] of law' that must be answered before affording Chevron deference." 58 But obviously those dissents do not speak for the Court.

The Supreme Court explained in Vermont Yankee that the APA's rulemaking provisions are basic, reflecting Congress's intent to leave much of rulemaking procedure to agency discretion. ${ }^{59}$ Thus, when courts impose procedural requirements on rulemaking that exceed the APA's minimal constraints, they may contravene congressional intent. For example, in Vermont Yankee, the Court held that the D.C. Circuit erred in requiring trial-type procedures in an informal rulemaking. ${ }^{60}$ Extant examples include the requirements that a final rule be a "logical outgrowth" proposed rule and that agencies provide public notice of the information they considered in formulating the rule, ${ }^{62}$ as well as the D.C. Circuit's requirement that ex parte contacts in informal rulemakings be disclosed (to the extent that requirement

58. 133 S. Ct. 1863, 1880 (2013) (Roberts, C.J., dissenting) (emphasis in original). Perhaps Justice Scalia and Chief Justice Roberts read Peter Strauss's article contending that Chevron merely expanded NLRB v. Hearst Publications, 322 U.S. 111 (1944): "In its first step, as in Hearst, a court will independently decide what authority has been conferred on an agency." Peter L. Strauss, Overseers or "The Deciders"- the Courts in Administrative Law, 75 U. CHI. L. REV. 815, 818 (2008). Thus, “[t]he court's independent conclusion of law might be that authority over some particular question of meaning . . . has been validly assigned to an administrative agency." Id. John Duffy suggested that if Chevron deference were contingent on explicit statutory delegations of rulemaking authority, it could be reconciled with the text of the APA. Duffy, supra note 16, at 199-207. By that reasoning, Mead may have moved Chevron over the line from common law to statutory interpretation. See Thomas W. Merrill \& Kristin E. Hickman, Chevron's Domain, 89 GEO. L.J. 833, 868-72 (2001) (arguing that Chevron doctrine is not common law but instead rests on congressional delegations of administrative authority). But see Mark Seidenfeld, Chevron's Foundation, 86 Notre DAME L. Rev. 273, 279-88 (2011); Patrick J. Smith, Chevron's Conflict with the Administrative Procedure Act, 32 VA. TAX REv. 813 (2013). Interestingly, in their empirical study of congressional drafting, Gluck and Bressman found that Mead is more reflective of Congress's actual practices than any other canon "except perhaps Chevron." Gluck \& Bressman, Part I, supra note 42, at 994; see also id. at 999.

59. See Vt. Yankee Nuclear Power Corp. v. NRDC, 435 U.S. 519, 524, 545-46 (1978) (discussing legislative history).

60. Id. at $523-24$.

61. See Beermann, supra note 30 , at 8 .

62. Am. Radio Relay League v. FCC, 524 F.3d 227, 245-46 (D.C. Cir. 2008) (Kavanaugh, J., concurring in part and dissenting in part) ("[T]he Portland Cement doctrine cannot be squared with the text of $\S 553$ of the APA."); Beermann, supra note 30 , at 8; Beermann \& Lawson, supra note 5, at 892-99; see also Metzger, supra note 24, at 509 ("[C] urrent requirements of notice and agency response to comments far exceed[] what the text of the APA suggests was originally expected."); Scalia, supra note 12, at 380-81 \& n.154. But see Jack M. Beermann, Rethinking Notice 2 (Boston U. Sch. of Law, Working Paper No. 13-49, 2013), available at http://papers.ssrn.com/sol3/papers.cfm?abstract_id=2349716 ("[T]here is a good instrumental case to be made against strict adherence to the text of the APA and in favor of requiring a new round of notice and comment when agencies make unanticipated changes to their proposals when promulgating final rules."); Peter L. Strauss, Statutes That Are Not Static-The Case of the APA, 14 J. CONTEMP. LEGAL Issues 767, 79698 (2005) (arguing that the Freedom of Information Act reshaped the meaning of the notice provisions in $\S 553)$. 
survives $)^{63}$ and its demand for open-mindedness in rulemaking. ${ }^{64}$ As this Article goes to press, the Supreme Court is poised to decide whether the D.C. Circuit erred in requiring the Department of Labor to go through notice and comment procedures before changing an interpretive rule even though the APA expressly exempts interpretive rules from the notice and comment provisions. ${ }^{65}$ While these common law requirements do not attempt to judicialize rulemaking to the extent that the D.C. Circuit did in Vermont Yankee, they nonetheless exceed section 553's minimal provisions and may contradict Congress's intent "that the discretion of the agencies and not that of the courts be exercised in determining when extra procedural devices should be employed." 66

Perhaps administrative common law has survived because, as we get further away from 1946, the monumental legislative effort that went into enacting the APA almost seventy years ago becomes less salient to modern judges than concerns about procedural fairness in a growing administrative state ${ }^{67}$ Regardless of the reason for its longevity, the courts are not open about their development of administrative common law, and they have not explained why it is permissible in some circumstances but not others, much less grappled with the constitutional concerns administrative common law raises. ${ }^{68}$

While scholars have long endorsed administrative common law, ${ }^{69}$ Gillian Metzger provides its strongest defense. She argues that, because administrative common law is important, inevitable, and legitimate, the courts should acknowledge its existence and be more transparent about its employment. ${ }^{70}$ Even Metzger's defense, however, cannot save administrative common law from the deliberative deficiency that superstatute theory reveals, as explained in Part IV. To set up that argument, I first describe superstatute theory, apply it to the APA, and explore the interpretive consequences of that exercise.

63. Beermann \& Lawson, supra note 5, at 885 (recognizing that the D.C. Circuit has narrowed, but "never expressly disavowed the doctrine"); see also Lisa Schultz Bressman, Procedures as Politics in Administrative Law, 107 ColuM. L. Rev. 1749, 1788 (2007) ("[T]he D.C. Circuit has vacillated as to whether a ban on ex parte communications in informal proceedings is consistent with Overton Park or at odds with Vermont Yankee.").

64. Beermann \& Lawson, supra note 5, at 889.

65. Mortg. Bankers Ass'n v. Harris, 720 F.3d 966 (D.C. Cir. 2013), cert. granted, 134 S. Ct. 2820 (2014); see also 5 U.S.C. § 553(b)(A) (2012); Sunstein \& Vermeule, supra note 14, at 432 ("[T] he Paralyzed Veterans rule is best seen as a form of federal common law . ...").

66. Vt. Yankee Nuclear Power Corp. v. NRDC, 435 U.S. 519, 546 (1978).

67. Beermann, supra note 30 , at 27.

68. Id. at 2, 5, 29; Davis, Administrative Common Law, supra note 16, at 5-6; see also Kovacs, Leveling, supra note 38, at 600-02, 604.

69. See supra note 16. "Leading administrative law theorists in the post-New Deal period, like Professors Louis Jaffe and Kenneth Culp Davis, openly celebrated administrative law's common law character." Metzger, supra note 16, at 1317. Jaffe and Davis's endorsement of administrative common law "is understandable, for the decades in which they worked ... marked the era of the 'New Federal Common Law,' so named by Judge Friendly's famous 1964 article." Duffy, supra note 16, at 136.

70. Metzger, supra note 16. 


\section{ESKRIDGE AND FEREJOHN'S THEORY OF SUPERSTATUTES}

\section{A. Identifying Superstatutes}

Others used the term "superstatute" before Eskridge and Ferejohn, ${ }^{71}$ but they are the only ones to have developed a theory of constitutional change centered on superstatutes. ${ }^{72}$ Eskridge and Ferejohn start from the premise that " $[\mathrm{n}] \mathrm{ot}$ all statutes are created equal" and employ the term superstatute to represent those statutes that "successfully penetrate public normative and institutional culture in a deep way."73 Because they result from a public, deliberative process and survive efforts to dilute their central ideas, superstatutes take on a "normative gravity" that ordinary statutes do not attain. ${ }^{74}$ Status as a superstatute affects how the superstatute itself is and ought to be interpreted. These "quasi-constitutional" enactments also provide a "normative backdrop, influencing the way other statutes are read and applied," 75 and because superstatutes reflect deep deliberation and broad public support, they should also influence the Supreme Court's interpretation of the Constitution. ${ }^{76}$

Eskridge and Ferejohn identify many federal superstatutes: the statute creating the Bank of the United States; ${ }^{77}$ the Federal Judiciary Act of 1789 , including the

71. E.g., 1 Bruce Ackerman, We the People: Foundations 91 (1991); Eugene Gressman \& Angela C. Carmella, The RFRA Revision of the Free Exercise Clause, 57 Оно St. L.J. 65, 111 (1996); Stephen M. Griffin, The Problem of Constitutional Change, 70 TuL. L. Rev. 2121, 2141 (1996); Michael W. McConnell, The Forgotten Constitutional Moment, 11 Const. Comment. 115, 142 (1994); Henry Paul Monaghan, Stare Decisis and Constitutional Adjudication, 88 Colum. L. REv. 723, 770 n.266 (1988); Max Radin, The Myth of Magna Carta, 60 HARV. L. REV. 1060, 1075 (1947).

72. Ackerman distinguished his thesis from Eskridge and Ferejohn's superstatute theory: "I am concerned with landmark statutes that deserve full admission into the constitutional canon, while they deal with a broader class of super-statutes that deserve quasi-constitutional status of a lesser, but still very significant, kind.” Bruce Ackerman, The Living Constitution, 120 Harv. L. Rev. 1737, 1753 n.38 (2007) (emphasis in original). Superstatute theory has a broader conception of legal change than Ackerman advances insofar as superstatutes "acquire their normative force through a series of public confrontations and debates over time and not through a single stylized dramatic confrontation.” Eskridge \& Ferejohn, Super-Statutes, supra note 9, at 1270; see also id. at 1271.

73. Eskridge \& Ferejohn, Super-Statutes, supra note 9, at 1215; see also Eskridge, America's Statutory "constitution," supra note 9, at 6; Eskridge \& Ferejohn, Super-Statutes, supra note 9.

74. Eskridge \& Ferejohn, Super-Statutes, supra note 9, at 1216; see also ESKRIDGE \& Ferejohn, Republic, supra note 9, at 27.

75. Eskridge \& Ferejohn, Super-Statutes, supra note 9, at 1265-66; see also ESKRIDGE \& FEREJOHN, RePUBLIC, supra note 9, at 59.

76. Eskridge, America's Statutory "constitution," supra note 9, at 39-40; see also ESKRIDGE \& FEREJOHN, REPUBLIC, supra note 9, at 6, 27, 102, 437-44.

77. Act of Feb. 25, 1791, ch. 10, 1 Stat. 191; see also Eskridge \& Ferejohn, Super-Statutes, supra note 9 , at $1223-25$. 
Rules Decision Act; ${ }^{78}$ the Civil Rights Acts of $1866^{79}$ and $1871 ;^{80}$ the Sherman Antitrust Act of $1890 ;{ }^{81}$ the Federal Arbitration Act of $1926,{ }^{82}$ the Norris-LaGuardia Act of $1932 ; 83$ many New Deal statutes, including the Securities Act of $1933,{ }^{84}$ the Securities Exchange Act of $1934,{ }^{85}$ the National Labor Relations Act of $1935,{ }^{86}$ and the Fair Labor Standards Act of $1938,{ }^{87}$ the Food, Drug, and Cosmetic Act of $1938 ;{ }^{88}$ the Civil Rights Act of $1964 ;{ }^{89}$ the Voting Rights Act of $1965 ;{ }^{90}$ the Clean Air Act of $1970^{91}$ and Clean Water Act of $1972 ; ;^{92}$ the Pregnancy Discrimination Act of $1978 ;{ }^{93}$ and the Family and Medical Leave Act of $1993,{ }^{94}$ among others. They also include "state statutory convergences," like the married

78. The Federal Judiciary Act of 1789, ch. 20, 1 Stat. 73; see also Eskridge \& Ferejohn, Super-Statutes, supra note 9, at 1223 n.22.

79. The Civil Rights Act of 1866, 14 Stat. 27 (codified at 42 U.S.C. $\S \S 1981-1982$ (2012)); see also Eskridge \& Ferejohn, Super-Statutes, supra note 9, at 1225-26.

80. The Civil Rights Act of 1871, 17 Stat. 13 (codified at 42 U.S.C. $§ 1983$ (2012)); see also Eskridge \& Ferejohn, Super-Statutes, supra note 9, at 1225-26.

81. The Sherman Antitrust Act, 26 Stat. 209 (1890) (codified at 15 U.S.C. §§ 1-7 (2012)); see also Eskridge \& Ferejohn, Super-Statutes, supra note 9, at 1231-32; ESKRIDGE \& Ferejohn, RePublic, supra note 9, at 121.

82. Eskridge \& Ferejohn, Super-Statutes, supra note 9, at 1260-61.

83. The Norris-La Guardia Act, ch. 90, 47 Stat. 70 (codified at 29 U.S.C. $\S \S 101-115$ (2012)); see also Eskridge \& Ferejohn, Super-Statutes, supra note 9, at 1227.

84. The Securities Act of 1933, Pub. L. No. 73-22, 48 Stat. 74 (codified at 15 U.S.C. $\S \S 77 \mathrm{a}-77 \mathrm{bbbb}$ (2012)); see also Eskridge \& Ferejohn, Super-Statutes, supra note 9, at 1227.

85. The Securities Exchange Act of 1934, Pub. L. No. 73-291, 48 Stat. 881 (codified at 15 U.S.C. §§ 78a-78111 (2012)); see also Eskridge \& Ferejohn, Super-Statutes, supra note 9, at 1227.

86. The National Labor Relations Act of 1935, Pub. L. 74-198, 49 Stat. 449 (codified at 29 U.S.C. $§ § 151-169$ (2012)); see also Eskridge \& Ferejohn, Super-Statutes, supra note 9, at 1227.

87. The Fair Labor Standards Act of 1938, Pub. L. 75-718, 52 Stat. 1060 (codified at 29 U.S.C. §§ 201-205 (2012)); see also Eskridge \& Ferejohn, Super-Statutes, supra note 9, at 1227.

88. The Food, Drug, and Cosmetic Act of 1938, Pub. L. No. 75-717, 52 Stat. 1040 (codified as amended at 21 U.S.C. § 301 (2012)); see also Eskridge \& Ferejohn, Super-Statutes, supra note 9, at 1257.

89. The Civil Rights Act of 1964, Pub. L. No. 88-352, 78 Stat. 241 (codified as amended in scattered sections of 5, 28, and 42 U.S.C. (2012)); see also Eskridge \& Ferejohn, Super-Statutes, supra note 9, at 1237; ESKRIDGE \& FEREJOHN, REPUBLIC, supra note 9, at 88.

90. The Voting Rights Act of 1965, Pub. L. No. 89-110, 79 Stat. 437 (codified as amended in scattered sections of 52 U.S.C. (2012)); see also ESKRIDGE \& FEREJOHN, REPUBLIC, supra note 9 , at $88,117$.

91. The Clean Air Act, Pub. L. No. 88-206, 77 Stat. 392 (1970) (codified as amended at 42 U.S.C. §§ 7401-7642 (2012)); see also ESKRIDGE \& FEREJOHN, REPUBLIC, supra note 9, at 301.

92. The Clean Water Act, Pub. L. No. 92-500, 86 Stat. 816 (1972) (codified as amended at 13 U.S.C. $\S$ 1251-1387 (2012)); see also ESKRIDGE \& FEREJOHN, REPUBLIC, supra note 9, at 301.

93. The Pregnancy Discrimination Act of 1978, Pub. L. No. 95-555, 92 Stat. 2076 (codified at 42 U.S.C. $\S 2000 \mathrm{e}(\mathrm{k})$ (2012)); see also Eskridge, America's Statutory "constitution," supra note 9, at 36.

94. The Family and Medical Leave Act of 1993, Pub. L. No. 103-3, 107 Stat. 6 (codified at 29 U.S.C. $§ 2601$ (2012)); see also ESKRIDGE \& FEREJOHN, REPUBLIC, supra note 9, at 58-59. 
women's property laws and no-fault divorce, ${ }^{95}$ as well as international agreements, like the Geneva Conventions. ${ }^{96}$

Under Eskridge and Ferejohn's theory, superstatutes typically exhibit several characteristics. First, superstatutes "alter substantially the then-existing regulatory baselines with a new principle or policy." 97 They "seek[] to establish a new normative or institutional framework." "98 Second, a superstatute's new principle "'sticks' in the public culture in a deep way, becoming foundational or axiomatic to our thinking." 99 It "prove[s] robust . . . over time." 100 Third, a superstatute has a "broad effect on the law-including an effect beyond the four corners of the statute." 101 A superstatute "will have colonizing effects on other statutes" and may have "a gravitational pull on constitutional law itself."102

Procedurally, a superstatute "emerges after a lengthy period of public discussion and official deliberation" and "passes the test of time." ${ }^{103}$ In A Republic of Statutes, Eskridge and Ferejohn present a series of case studies of statutes that became entrenched superstatutes. Typically, the story begins with Congress's statutory response to a broad "social movement." 104 Then the statute's supporters and administrators implement the statute in a practical way that makes progress toward the statute's goal and "avoid[s] the disasters predicted by opponents." 105 If the statute becomes "sufficiently valuable" to a growing segment of society, the statute will be consolidated when a new Congress reaffirms, and perhaps even expands, the original statute. ${ }^{106}$ Thus, the superstatute's new principle is "debated, honed, and strengthened through an ongoing give-and-take among the legislative, executive, and judicial branches." 107 Through this public, deliberative process, the statute "wins

95. Id. at $16,224,244$.

96. Id. at 16,419 .

97. Eskridge \& Ferejohn, Super-Statutes, supra note 9, at 1230; see also ESKRIDGE \& Ferejohn, Republic, supra note 9, at 26; Eskridge \& Ferejohn, Super-Statutes, supra note 9, at 1219 .

98. Eskridge \& Ferejohn, Super-Statutes, supra note 9, at 1216.

99. Id. at 1231; see also ESKRIDGE \& FEREJOHN, REPUBLIC, supra note 9, at 26; Eskridge \& Ferejohn, Super-Statutes, supra note 9, at 1216, 1230, 1273.

100. Eskridge \& Ferejohn, Super-Statutes, supra note 9, at 1216.

101. Id.

102. Id. at 1235-36; see also ESKRIDGE \& FEREJOHN, REPUBLIC, supra note 9, at 214-16; Eskridge \& Ferejohn, Super-Statutes, supra note 9, at 1240-42.

103. Eskridge \& Ferejohn, Super-Statutes, supra note 9, at 1231, 1273; see also ESKRIDGE \& Ferejohn, RePublic, supra note 9, at 26; Eskridge \& Ferejohn, Super-Statutes, supra note 9, at 1237.

104. ESKRIDGE \& FEREJOHN, REPUBLIC, supra note 9, at 123; see also id. at 104-05.

105. Id. at 17; see also id. at 111,121, 123, 166, 186. Eskridge and Ferejohn call this process of implementing a putative superstatute "administrative constitutionalism." Id. at 26, 33, 186. They argue that administrative constitutionalism is "the dominant governmental mechanism for the evolution of America's fundamental normative commitments." Id. at 33; see also id. at 72-73, 214, 266; cf. Gillian E. Metzger, Administrative Constitutionalism, 91 TEX. L. REV. 1897 (2013) (arguing for a broad conception of "administrative constitutionalism").

106. ESKRIDGE \& FEREJOHN, REPUBLIC, supra note 9, at 17; see also id. at 105, 111, 123, $166,422$.

107. Eskridge \& Ferejohn, Super-Statutes, supra note 9, at 1237; see also ESKRIDGE 
over skeptics," 108 and the new principle becomes "entrenched ... into American public life." 109 Then "we'd say the law has become a superstatute." 110 Though superstatutes ultimately must yield to the Constitution, through extended public deliberation and evolution they acquire a "normative force" 111 that makes them "resistant to change" and "gives them a power beyond their formal legal ambit." 112

Eskridge and Ferejohn argue that the evolution of public law through superstatutes, which they term "small 'c' constitutionalism," 113 is normatively superior to amendments of the large "C" Constitution. ${ }^{14}$ The "fundamental institutions and norms of our democracy" must be stable over time, adaptable to new circumstances, and legitimized through "popular deliberation." 115 Superstatutes meet those qualifications. ${ }^{116}$ They "provide[] a mechanism whereby a great principle can be recognized and entrenched, but the details worked out by experts and institutions" and then altered to respond to changing circumstances. ${ }^{117}$ The Constitution, on the other hand, is "too old to answer most of the looming social, political, and moral questions that Americans want answered"::118 it is too difficult to amend through the Article V process; ${ }^{119}$ it governs only government, not private, action; ${ }^{120}$ and it does not address the government's duty "to create and guarantee affirmative and positive legal regimes" that give citizens "ample room to make the choices that fulfill their needs and desires." 121

Eskridge and Ferejohn also posit that the law is better developed through superstatutes than through judicial constitutional interpretation. ${ }^{122}$ "[A] really thoughtful decision by nine unelected wise people is not as legitimate as a decision made by elected officials with popular input and the possibility of serious contestation afterwards." 123 The ongoing, dynamic, republican deliberation that superstatutes endure gives "more opportunities for meaningful public input" and thus is "more legitimate and . . . more productive" than judicial constitutional change. ${ }^{124}$ Consequently, the Supreme Court's greatest "Constitutional triumphs" have been in

\& FEREJOHN, RePublic, supra note 9, at 7, 19, 78, 454; Eskridge \& Ferejohn, Super-Statutes, supra note 9 , at 1273 .

108. ESKRIDGE \& FEREJOHN, RePUBLIC, supra note 9, at 111.

109. Eskridge \& Ferejohn, Super-Statutes, supra note 9, at 1237.

110. ESKRIDGE \& FEREJOHN, REPUBLIC, supra note 9, at 111.

111. Eskridge \& Ferejohn, Super-Statutes, supra note 9, at 1270.

112. ESKRIDGE \& FEREJOHN, REPUBLIC, supra note 9, at 8; see also id. at 13, 27, 28, 64.

113. Id. at 1 .

114. Eskridge \& Ferejohn, Super-Statutes, supra note 9, at 1271-76; see also ESKRIDGE \& FEREJOHn, RePublic, supra note 9, at 8-9, 374.

115. Eskridge, America's Statutory “constitution," supra note 9, at 44.

116. See ESKRIDGe \& FEREJOHN, Republic, supra note 9, at 18; see also id. at 303.

117. Id. at 122; see also id. at 263,334 .

118. Id. at 4; see also id. at 37-38.

119. Id. at 4, 49-51, 73.

120. Id. at $4,25-26$.

121. Id. at 4-5, 22 (emphasis in original); see also id. at 9, 25, 42-48, 51-54, 91-95.

122. See Eskridge \& Ferejohn, Super-Statutes, supra note 9, at 1271-76.

123. Eskridge, America's Statutory “constitution," supra note 9, at 35.

124. ESKRIDGE \& FEREJOHN, REPUBLIC, supra note 9, at 167; see also id. at 445. 
cases where the Court's interpretation of the Constitution paralleled norms that had already become entrenched in superstatutes. ${ }^{125}$

\section{B. Interpreting Superstatutes}

Eskridge and Ferejohn's work is focused on small "c" constitutional change and the process by which statutes become entrenched superstatutes. A related, but separate part of their theory concerns the interpretation of superstatutes. That part of their theory is not developed as fully but they provide ample material to feed a discussion of how the APA should be interpreted.

Eskridge and Ferejohn argue that superstatutes are and should be interpreted differently from ordinary statutes and more like the Constitution. ${ }^{126}$ Descriptively, they argue that, as superstatutes age, they often reach "beyond and even against the original congressional expectations." ${ }^{\prime 27}$ This superstatutory evolution is inevitable, according to Eskridge and Ferejohn, for three reasons. First, superstatutes tend to be written using broad language because "they are aimed at big problems and must last a long time." 128 Even the agency's initial application of the statute to specific circumstances "will typically go beyond the expectations, or even the imagination, of the enacting Congress." 129 Second, the agency officials who implement the statute have audiences, constituencies, perspectives, and ethical duties that differ from the statute's authors in Congress, and those differences grow as time passes. ${ }^{130}$ Third, agencies are continually pressed to interpret the statute "to be responsive to new facts, new needs, [and] new ideas," and "current rather than historical political preferences." 131

Superstatutory interpretive evolution is normatively desirable, according to Eskridge and Ferejohn, because it is more adaptive than Constitutional change. ${ }^{132}$ Hence, Eskridge and Ferejohn contend that both courts and agencies should interpret superstatutes in a purposive and dynamic fashion, applying the terms "broadly and evolutively" 133 to implement "statutory purpose and principle as well as compromises suggested by statutory texts." 134 "Because they evolve, common-law style," the interpretation of superstatutes should not be bound by Congress's original intent to the same extent as ordinary statutes. ${ }^{135}$ Thus, Eskridge and Ferejohn argue that courts interpreting superstatutes should be attentive to Congress's purposes,

125. Id. at 9; see also id. at 102, 350, 433.

126. See id. at 292.

127. Id. at 263; see also id. at 267.

128. Id. at 267.

129. Id.

130. Id. at 270 .

131. Id. at $272-73$.

132. Id. at 263, 303, 334; Eskridge, America's Statutory "constitution," supra note 9, at $30-34$.

133. Eskridge \& Ferejohn, Super-Statutes, supra note 9, at 1249.

134. Id. at 1247; see also ESKRIDGE \& FEREJOHN, REPUBLIC, supra note 9, at 291, 293. Eskridge contends that a statute's purpose changes over time as interpreters apply the statute to new circumstances. William N. ESKRIDGE, JR., DyNAMiC Statutory INTERPRETATION 30-31 (1994).

135. Eskridge \& Ferejohn, Super-Statutes, supra note 9, at 1252. 
examine the statute's ongoing legislative and administrative history, and give agencies room to change their interpretations. ${ }^{136}$

At first glance, it looks like superstatute theory would support administrative common law. Yet, applying superstatute theory to the APA yields an unexpected result because the APA is not a typical superstatute. Typically, federal superstatutes are implemented and interpreted by a single agency; the APA is not. ${ }^{137}$ Single-agency implementation is not a requirement for a statute to become entrenched; "there are different paths toward entrenchment." 138 For example, state statutory convergences may become entrenched despite the lack of a single agency at the center of the interpretive universe. Nonetheless, single-agency implementation is central to Eskridge and Ferejohn's contention that superstatutes inevitably evolve and ought to evolve. That superstatutory evolution may be legitimized by an election. Absent such direct public engagement, however, Eskridge and Ferejohn ground the legitimacy of superstatutory evolution on single-agency implementation and interpretation with a strong connection to the public. ${ }^{139}$

Eskridge and Ferejohn have not addressed statutes like the APA in their work on superstatutes, but superstatute theory provides a valuable tool for exploring how the APA should be interpreted. Applying the theory to the APA enhances superstatute theory as well by applying it to a new category of statutes. In the next Part, I demonstrate that the APA has the characteristics of a superstatute.

\section{THE APA Is A SUPERSTATUTE}

Although Eskridge and Ferejohn have not identified the APA as a superstatute, they have acknowledged its importance. Eskridge argued that statutes and regulations are "the primary source of constitutional structures, rules, and rights in our polity" and the APA provides the framework for much of that lawmaking. ${ }^{140} \mathrm{In}$ their recent book, Eskridge and Ferejohn contend that "most legally binding rules" are generated by agencies pursuant to congressional delegations of lawmaking authority. ${ }^{141}$ The APA, therefore, provides the "framework for understanding most national lawmaking and much national adjudication." 142

In this Part, I demonstrate that, like the Voting Rights Act, the APA is entrenched; it "propounded a bold new principle of law that was enthusiastically received in Congress, was aggressively implemented ..., has been accepted by Americans of all political persuasions, and has been repeatedly reaffirmed by Congress." ${ }^{143} \mathrm{We}$ the

136. See Eskridge \& Ferejohn, Republic, supra note 9, at 293-302. In addition, interpreters should never forget the government's "core meta-purposes," like ensuring security and equality. See id. at 465-66.

137. See infra Part III.B.

138. ESKRIDGE \& FEREJOHN, REPUBLIC, supra note 9, at 115.

139. See infra Part III.A.

140. Eskridge, America's Statutory “constitution," supra note 9, at 5, 12.

141. ESKRIDGE \& FEREJOHN, REPUBLIC, supra note 9, at 10.

142. Id.

143. See id. at 117. But see Shelby Cnty. v. Holder, 133 S. Ct. 2612 (2013) (invaliding coverage formula in section 4(b) of the Voting Rights Act). 
people "have embraced [its] core principle, and any effort to upend it would be met with popular unease or outrage." 144

This discussion lays the foundation for my argument that judicial interpretation of the APA should focus on public deliberation. But I should not have to work too hard to convince readers that the APA is a superstatute. As Adrian Vermeule pointed out, if you assembled one hundred legal scholars and asked them to list superstatutes, "[a] handful of statutes will appear on most lists - say, the Administrative Procedure Act of 1946, which is in many respects the fundamental framework for the modern American regulatory state, yet which Eskridge and Ferejohn oddly mention only in passing." 145

\section{A. Emerged from a Long Period of Deliberation}

With the rise of the administrative state in the early twentieth century came the conservative drive for administrative reform. ${ }^{146}$ The American Bar Association (ABA) led the charge, voicing its concerns through its Special Committee on Administrative Law, which the ABA's Executive Committee created in May 1933 in response to the first New Deal. ${ }^{147}$ Over the years, the ABA's Special Committee met, issued reports, and proposed legislation on numerous occasions. ${ }^{148}$ Before 1937, however, when the Supreme Court was keeping New Deal programs at bay, ${ }_{149}$ the ABA's proposals gained no traction in Congress. ${ }^{150}$ In 1938, "[t] he decibel count rose markedly." 151 The Supreme Court had begun to uphold New Deal programs, ${ }^{152}$ and although Democrats retained control of Congress, Republicans gained enough seats to strengthen their coalition with conservative Democrats in the drive for administrative reform. ${ }^{153}$ The Senate Judiciary Committee held eight days of

144. ESKRIDGE \& FEREJOHN, REPUBLIC, supra note 9, at 117.

145. Vermeule, supra note 23. But see Ackerman, supra note 72, at 1750 ("The trouble comes when we compare the cases and landmark statutes on our lists. Mine might contain the Administrative Procedure Act, but yours might not."); Frymer, supra note 9, at 234-35 (suggesting that the APA might or might not appear on one's list of superstatutes).

146. Paul Frymer contends that "almost all of the superstatues [Eskridge and Ferejohn] engage derived initially from progressive movements on the left." Frymer, supra note 9, at 235. A notable exception is the Federal Reserve Act, Pub. L. No. 63-43, 38 Stat. 251 (1913) (codified in scattered sections of 12 U.S.C. ch. 3 (2012)), which resulted from the pressure of corporate capitalists and bankers. See ESKRIDGE \& FEREJOHn, REPUBLIC, supra note 9, at 335-39.

147. See Kovacs, A History, supra note 39, at 682.

148. See, e.g., id. at 679, 682, 684-85, 693-96; Shepherd, supra note 3, at 1569-77, 1582-83, 1588-94, 1639-40, 1644-47, 1649-50.

149. See, e.g., Louisville Joint Stock Land Bank v. Radford, 295 U.S. 555 (1935) (striking down the Frazier-Lemke Act); A.L.A. Schechter Poultry Corp. v. United States, 295 U.S. 495 (1935) (invalidating regulations issued under the National Industrial Recovery Act).

150. Kovacs, A History, supra note 39, at 681-83; Shepherd, supra note 3, at 1569.

151. Walter Gellhorn, The Administrative Procedure Act: The Beginnings, 72 VA. L. REV. 219, 221 (1986).

152. See, e.g., NLRB v. Jones \& Laughlin Steel Corp., 301 U.S. 1 (1937) (upholding the National Labor Relations Act); W. Coast Hotel v. Parrish, 300 U.S. 379 (1937) (upholding minimum wage law for women and minors).

153. Kovacs, A History, supra note 39, at 683-84; Shepherd, supra note 3, at 1580-82, 1586. 
hearings on an administrative courts proposal early that year. ${ }^{154}$ That bill died in committee. ${ }^{155}$ The ABA's new proposal, introduced in Congress in 1939, came to be known as the Walter-Logan bill. ${ }^{156}$

In an effort "to deflect the new momentum for strict control of agencies that the introduction of the ABA bill had sparked," President Roosevelt instructed the Attorney General to form a committee to study administrative reform. ${ }^{157}$ The Attorney General's Committee on Administrative Procedure included twelve practitioners, judges, and professors - eight New Deal supporters and four conservatives. ${ }^{158}$ The Attorney General's Committee constructed an enormous record of current administrative practices and discussed potential legislative proposals. ${ }^{159}$ For each of twenty-seven federal agencies, the Committee staff interviewed agency officers and employees, as well as lawyers who practiced before the agency; drafted a monograph about the agency; solicited comments on the draft from the agency; and held public hearings. ${ }^{160}$

Meanwhile, Congress debated the Walter-Logan bill extensively. A subcommittee of the House Judiciary Committee held hearings on April 5, 1939. ${ }^{161}$ The Senate debated the bill on June 13, 1939, and the issue "began to attract intense national attention." 162 The House debate spanned four days in April 1940, and the bill passed the House by a vote of 282 to $96 .{ }^{163}$ The Senate debated the bill again on November 19, 1940, and passed the bill with amendments by a vote of 27 to $25 .{ }^{164}$ The House debated and concurred in the Senate amendments by a vote of 176 to 51 on December 2, 1940. ${ }^{165}$ All in all, the floor debates leading to the passage of the Walter-Logan bill span more than one hundred pages in the Congressional Record. ${ }^{166}$

President Roosevelt vetoed the Walter-Logan bill in part because he wanted to wait for the report of the Attorney General's Committee "before approving any measure in this complicated field." 167 The House debated the bill again and fell 34

154. Shepherd, supra note 3, at $1588-89$.

155. Id. at 1588-90.

156. Kovacs, A History, supra note 39, at 685.

157. Shepherd, supra note 3, at 1594.

158. Id. at 1595 .

159. See Comm. on Admin. Procedure, Administrative Procedure in Government AgEnCies, S. Doc. No. 77-8 (1941) [hereinafter AG's COMMitTEE REPORT].

160. A.H. Feller, Administrative Law Investigation Comes of Age, 41 ColuM. L. REV. 589, 589-90 (1941); see also Shepherd, supra note 3, at 1596. The Committee's staff included Walter Gellhorn and Kenneth Culp Davis. Id. at 1595.

161. Administrative Law: Hearings on H.R. 4236, H.R. 6198, and H.R. 6324 Before Subcomm. No. 4 of the H. Comm. on the Judiciary, 76th Cong. 19 (1939).

162. Shepherd, supra note 3, at 1602; see also 84 CONG. REC. 7075-78 (1939).

163. Kovacs, A History, supra note 39, at 688-89; Shepherd, supra note 3, at 1606, 1619; see also 86 CONG. REC. 4742-44 (1940).

164. Shepherd, supra note 3, at 1620-22; see also 86 CoNG. REC. 13,747-48 (1940).

165. 86 CONG. REC. 13,815-16 (1940).

166. 84 Cong. ReC. 7075-78 (1939); 86 ConG. ReC. 4530-48, 4590-605, 4646-75, 4722-44, 13,743-48, 13,807-16 (1940).

167. Franklin Delano Roosevelt, The President Vetoes the Bill Regulating Administrative Agencies, Note to the House of Representatives, Dec. 18, 1940, in 9 THE Public PAPERS AND AdDREsSEs of Franklin D. RoOsevelt 616, 620 (1941). 
votes short of overriding the President's veto. ${ }^{168}$ About a month later, the Attorney General's Committee issued its 474-page report. ${ }^{169}$ The report described the history of administrative government and the organization and procedure of existing agencies; discussed rulemaking, adjudication, and judicial review; and included two draft bills: a liberal "majority bill" and a conservative "minority bill." 170 Both bills were introduced in the Senate. ${ }^{171}$

In the spring and summer of 1941, the Senate Judiciary Committee held twenty-five days of hearings, producing a transcript of 1621 pages. ${ }^{172}$ The Committee heard from numerous agencies; members of the Attorney General's Committee; the $\mathrm{ABA}$ and other bar associations; and groups representing business interests and administrative practitioners, professors, and labor interests, among others. ${ }^{173}$ Before Congress could take further action on administrative reform, war came, and other matters commanded Congress's attention. ${ }^{174}$

Congress returned to the task of administrative reform two weeks after D-Day in 1944, when Senator McCarran and Representative Sumners introduced a bill that the ABA Committee had designed as a compromise between the Attorney General's Committee's majority and minority bills. ${ }^{175}$ McCarran and Sumners reintroduced a revised bill in the new Congress in 1945, and the House and Senate Judiciary Committees proceeded in private through a series of closed-door negotiations with the Attorney General and private interests, including the ABA. ${ }^{176}$ The Senate Judiciary Committee solicited comments on its first revision of the bill and formally submitted its next draft to the Attorney General, who endorsed the bill, as did the ABA. ${ }^{177}$ The Committee passed the bill unanimously and issued a 31-page report interpreting each of the bill's provisions. ${ }^{178}$ The House Judiciary Committee held three days of hearings in June $1945,{ }^{179}$ reported the bill unanimously with minor

168. Shepherd, supra note 3, at 1628, 1630.

169. AG's COMMITTEE REPORT, supra note 159.

170. See id.; see also Shepherd, supra note 3, at 1632-36.

171. S. 675, 77th Cong. (1941); S. 674, 77th Cong. (1941); see also Shepherd, supra note 3 , at 1636 .

172. Administrative Procedure: Hearings on S. 674, S. 675, and S. 918 Before Subcomm.

of the S. Comm. on the Judiciary, 77th Cong. (1941).

173. See id.

174. Many things changed during the war years, making the APA's passage possible. See Kovacs, A History, supra note 39, at 693-96.

175. S. 2030, 78th Cong. (1944); H.R. 5081, 78th Cong. (1944); see also 68 ANNUAL REPORT OF THE AMERICAN BAR ASSOCIATION 256 (1943); Shepherd, supra note 3, at 1649-50. The bill was revised and reintroduced in January 1945. S. 7, 79th Cong. (1945); H.R. 1203, 79th Cong. (1945).

176. Kovacs, A History, supra note 39, at 696-97, 701; Shepherd, supra note 3, at 1656, 1661.

177. Staff of S. Comm. on the Judiciary, $79^{\mathrm{TH}}$ Cong., Rep. ON the Administrative Procedure Act (Comm. Print 1945), reprinted in Administrative Procedure Act: Legislative History, 79TH Cong. 1944-46, at 11 (1946) [hereinafter Legislative History]; Kovacs, A History, supra note 39, at 699-700, 703; Shepherd, supra note 3, at $1659,1661-62$.

178. See S. ReP. No. 79-752 (1945), reprinted in LeGiSLATIVE HiSTORY, supra note 177, at 185; Shepherd, supra note 3, at 1662.

179. See Federal Administrative Procedure: Hearings on H.R. 184, H.R. 339, H.R. 1117, 
amendments, and issued a 48-page report. ${ }^{180}$ The bill passed the Senate and the House on voice votes that reportedly were unanimous, ${ }^{181}$ and President Truman signed the APA into law on June 11, 1946. ${ }^{182}$

In sum, the APA of 1946 represented Congress's response to a conservative movement and emerged from an enthusiastic Congress following years "of public discussion and official deliberation" 183 within and between Congress, the Executive Branch, the ABA, and the public. The APA easily satisfies the first characteristic for superstatute status.

\section{B. Altered Regulatory Baselines}

For a statute to achieve superstatute status, it should have changed common law and regulatory baselines. ${ }^{184}$ This is a characteristic, however, and not a rigid criterion. An entire chapter of Eskridge and Ferejohn's book is dedicated to the Sherman Act, ${ }^{185}$ which is a superstatute even though its "authors apparently thought they were federalizing the common law." 186 Statutory provisions that establish new law and those that restate existing law both may become so entrenched that they qualify as "super" within the meaning of superstatute theory.

Some of the APA codified existing standards and practices. ${ }^{187}$ Even before the APA was enacted, some agencies began to change their procedures in response to

H.R. 1203, H.R. 1206, and H.R. 2602 Before the H. Comm. on the Judiciary, 79th Cong. (1945), reprinted in LEGISLATIVE HISTORY, supra note 177, at 45-130.

180. H.R. ReP. No. 79-1980 (1946), reprinted in LeGisLative History, supra note 177, at 233-82; Shepherd, supra note 3, at 1669.

181. See Legislative History, supra note 177, at 344, 406, 423; Shepherd, supra note 3 , at 1668, 1674; The Federal "Administrative Procedure Act” Becomes Law, 32 A.B.A. J. 377 (1946) ("No votes were cast against it.").

182. The Administrative Procedure Act of 1946, Pub. L. No. 79-404, 60 Stat. 237 (codified as amended at 5 U.S.C. $\S \S 551-706(2012))$.

183. See Eskridge \& Ferejohn, Super-Statutes, supra note 9, at 1231.

184. See supra text accompanying notes 97-98.

185. ESKRIDGE \& FEREJOHN, REPUBLIC, supra note 9, at 119-64.

186. Eskridge \& Ferejohn, Super-Statutes, supra note 9, at 1234; see also Margaret H. Lemos, The Other Delegate: Judicially Administered Statutes and the Nondelegation Doctrine, 81 S. CAL. L. REV. 405, 429, 461-63 (2008).

187. See, e.g., Tom C. Clark, U.S. Dep't of Justice, Attorney General's Manual on THE Administrative Procedure ACt 61 (1947) (asserting that § 6(a) "restates existing law and practice that persons compelled to appear in person before an agency or its representative must be accorded the right to be accompanied by counsel"); see also SENATE JUDICIARY Committee Print (Comm. Print 1945), reprinted in Legislative History, supra note 177, at 11, 31 ("The provision relating to burden of proof is the standard rule."); H.R. REP. No. 79-1980 (1946), reprinted in LEGISLATIVE HISTORY, supra note 177, at 235, 276 (explaining that section 10(b) "does not alter venue provisions under existing law"); 92 CONG. REC. 5654 (1946) (statement of Rep. Francis Walter) (stating that the venue requirements codified existing law); Jerry L. Mashaw, Creating the Administrative Constitution: The Lost One HundRed YeARs of AMERICAN AdMinistrative LAW 310 (2012) (“Our contemporary transsubstantive administrative law is built on the foundation of administrative practices that long antedate the APA's codification."); id. at 311 (arguing that today's law "is in many ways a codification of the best practices generated in administrative law's first century"). 
the growing interest in administrative reform, ${ }^{188}$ leading the Attorney General's Committee to assert that "[i]n the best existing practices are embodied the fundamentals of fair administration." 189 That much of the Act codified existing law, however, does not detract from its status as a superstatute because the provisions that codified existing law are equally, if not more, entrenched than the provisions that created new law. Take, for example, the model of judicial review of agency action that parallels appellate court review of trial court judgments. Under the appellate review model, the court's review is based on a record produced by the agency, the standard of review is based on "conventional understandings" of the relative competence of the court and the agency, and those understandings "are grounded in the law-fact distinction." 190 Professor Merrill showed that this model of judicial review already had been imported into administrative law before it was incorporated into the APA, and it is now "so deeply entrenched in American political culture that it is impossible to imagine wrenching free from its influence." 191

In any event, many provisions of the APA were new. ${ }^{192}$ Certainly Congress would not have suffered with the Act for so many years merely to restate the common law. Members of Congress did not think that was all they had accomplished, ${ }^{193}$ and the Attorney General would not have needed to publish a manual advising agencies about complying with the new law ${ }^{194}$ if the new law were merely a restatement. In this Part, I highlight a few of the APA's more obvious breaks with preexisting administrative law and practice. ${ }^{195}$

188. See AG's Committee Report, supra note 159, at 4, 62; JoAnNa L. Grisinger, The Unwieldy American State: Administrative Politics Since the New Deal 79 (2012) (explaining that the APA reflected existing agency practice because agencies "had been trying to head off these and similar reforms for years").

189. See AG's Committee Report, supra note 159, at 5; see also Present at the Creation: Regulatory Reform Before 1946, supra note 32, at 521 ("A lot of the things that seem to me now to be accepted as good practice were . . . increasingly good practice at the time."); GRISINGER, supra note 188, at 77 (asserting that the APA "was an explicit statement of best practice that effectively indicated Congress's approval of much of what the administrative state already did").

190. Thomas W. Merrill, Article III, Agency Adjudication, and the Origins of the Appellate Review Model of Administrative Law, 111 ColuM. L. REV. 939, 941 (2011).

191. Id. at $942-43,1003$.

192. See GRISINGER, supra note 188, at 77; Mashaw, supra note 4, at 1367; Present at the Creation: Regulatory Reform Before 1946, supra note 32, at 518; id. at 521 (debating the extent to which the APA was "declaratory").

193. S. ReP. No. 79-752 (1945), reprinted in LegiSLATIVE History, supra note 177, at 193; Grisinger, supra note 188, at 60; Carl McFarland, Analysis of the Federal Administrative Procedure Act, in The Federal Administrative Procedure Act And the Administrative Agencies: Proceedings of an Institute Conducted by the New York University SchoOl OF LAW ON FEBRUARY 1-8, 1947 at 17, 23 (1947) [hereinafter NYU InSTITUTE] ("There certainly is no doubt that, in passing this statute, there was a desire for reform. Otherwise why would there have been so many bills, so many hearings, so many studies, so much talk? Congress does not legislate for the fun of it . ...").

194. See CLARK, supra note 187 , at 6 .

195. I leave for another day a discussion of which provisions of $\S 10$ governing judicial review changed preexisting law. 
One of Congress's central goals in enacting the APA was to impose some uniformity on federal agencies. ${ }^{196}$ When Congress was considering the Walter-Logan bill, the House and Senate Judiciary Committees lamented the lack of uniformity in administrative procedure and judicial review of administrative actions. ${ }^{197}$ Two years later, in the final report of the Attorney General's Committee on Administrative Procedure, both the liberal majority and the conservative minority recognized the need for more uniformity. ${ }^{198}$ When Congress returned to the task of administrative reform after the war, it reiterated its lament about the lack of uniformity in administrative law, but this time it followed through on its rhetoric. ${ }^{199}$ The Walter-Logan bill had included exemptions for numerous individual agencies, including the Federal Reserve Board, the Comptroller of the Currency, and the Federal Deposit Insurance Corporation. ${ }^{200}$ In the APA, Congress abandoned those exemptions. The Senate Judiciary Committee followed "the undeviating policy" of "deal[ing] with types of functions as such and in no case with administrative agencies by name." 201 The House followed the same path, explaining, "The bill is meant to be operative 'across the board' in accordance with its terms, or not at all. . . No agency has been favored by special treatment."202 Congress's desire for greater uniformity is reflected in the Act itself, from the broad definitions of "agency," "agency proceeding," and "agency action,"203 to section 12's direction that "all requirements or privileges relating to evidence or procedure" be applied equally to all agencies, and its provision that subsequent legislation could only "supersede or modify" the APA if it did so expressly. ${ }^{204}$

196. See Kovacs, Leveling, supra note 38, at 591, 608; see also Marshall J. Breger, The APA: An Administrative Conference Perspective, 72 VA. L. REV. 337, 344 (1986); Field et al., supra note 27, at 67; Metzger, supra note 16, at 1309.

197. S. REP. No. 76-442, at 9-10 (1939) (laying the blame for "the present situation of indescribable confusion" primarily at Congress's feet for allowing the administrative state to grow "without regard to any uniformity"); H.R. REP. No. 76-1149, at 3 (1939) (same).

198. See AG's COMmitTEE REPORT, supra note 159, at 20, 192, 213. Not everyone agreed. See John Foster Dulles, The Effect in Practice of the Report on Administrative Procedure, 41 Colum. L. REv. 617, 623 (1941) (opining that the Attorney General's Committee had "gone further than might be wise in attempting to deal through general legislation with all types of administrative process").

199. H.R. ReP. No. 79-1980 (1946), reprinted in LegiSLATIVE History, supra note 177, at 243 (quoting S. REP. No. 76-442, at 9-10 (1939)); Nathaniel L. Nathanson, Some Comments on the Administrative Procedure Act, 41 ILL. L. REV. 368, 371 (1946) (commenting that, compared to the Walter-Logan bill, the APA "is noteworthy for the breadth of its coverage").

200. Kovacs, A History, supra note 39, at 684, 687; Kovacs, Leveling, supra note 38, at 589.

201. S. REP. No. 79-752 (1945), reprinted in LEGISLATIVE HISTORY, supra note 177, at 187, 191.

202. H.R. REP. No. 79-1980 (1946), reprinted in LEGISLATIVE HISTORY, supra note 177, at $235,250$.

203. Id. at 255; S. ReP. No. 79-752 (1945), reprinted in LEGISLATIVE HiSTORY, supra note 177, at 187, 197-98; Field et al., supra note 27, at 67.

204. Administrative Procedure Act, Pub. L. No. 79-404, § 12, 60 Stat. 237, 244 (1946) (codified at 5 U.S.C. $§ 559$ (2012)); see also Marcello v. Bonds, 349 U.S. 302, 310 (1955) ("Exemptions from the terms of the Administrative Procedure Act are not lightly to be presumed in view of the statement in $\S 12$ of the Act that modifications must be express."). 
After the APA's passage, former adversaries agreed that the Act was designed to increase uniformity. ${ }^{205}$ Even the Attorney General agreed that the APA "sets a pattern designed to achieve relative uniformity in the administrative machinery of the Federal Government." ${ }^{206}$ Within a few years, the Supreme Court joined the chorus in Wong Yang Sung v. McGrath, commenting that the Act was intended "to introduce greater uniformity of procedure and standardization of administrative practice among the diverse agencies whose customs had departed widely from each other." ${ }^{207}$ The following year, in Universal Camera Corporation v. NLRB, the Court reiterated that the APA reflected a desire for uniformity, ${ }^{208}$ and the Court has sustained the uniformity refrain. ${ }^{209}$ Of course, Congress itself has undermined its own effort to enhance uniformity by enacting numerous statutory overlays governing particular agencies. ${ }^{210}$ But the APA certainly broke with the past in establishing a uniform floor for administrative procedure and judicial review of administrative action. ${ }^{211}$

Another way in which the APA altered regulatory baselines was in requiring agencies to publish their rules of organization and procedure. Prior to the APA, the Federal Register Act of 1935 required agencies to publish their substantive regulations in the Federal Register, but they were not required to formulate, much

205. Carl McFarland, Analysis of the Federal Administrative Procedure Act, in NYU INSTITUTE, supra note 193, at 22 (noting that "a very important purpose of the statute was to standardize and simplify"); Bernard Schwartz, Administrative Procedure and the A.P.A., 24 N.Y.U. L.Q. REV. 514, 514 (1949) (stating that the APA prescribed "[u]niform standards of fairness ... for all federal administrative action").

206. Clark, supra note 187, at 5; see also id. at 9; S. ReP. No. 79-752 (1945); Legislative HistORY, supra note 177, at 224 (Letter from Attorney General Clark).

207. 339 U.S. 33, 41 (1950). The Court supported this statement with citations to the House report on the APA, the Attorney General's Committee report, and Carl McFarland's statement at the NYU Institute, as well as the House and Senate reports and the House hearings on the Walter-Logan bill. Id. Congress overruled the Court's holding that the APA governed deportation hearings "almost immediately afterward." Ardestani v. INS, 502 U.S. 129, 133 (1991).

208. 340 U.S. 474, 489 (1951).

209. Dickinson v. Zurko, 527 U.S. 150, 155 (1999) (holding the APA governs review of Patent and Trademark Office findings of fact and allowing "grandfathered common-law variations" to persist based on ambiguous authority would undermine Congress's intent to enhance uniformity in administrative law); Dir., Office of Workers' Comp. Programs, Dep't of Labor v. Greenwich Collieries, 512 U.S. 267, 280-81 (1994) (holding that allowing agencies to devise their own rules governing the burden of proof in adjudications would undermine the APA's goal of achieving greater uniformity in administrative practice); $c f$. Douglas v. Indep. Living Ctr. of S. Cal., Inc., 132 S. Ct. 1204, 1211 (2012) (indicating that allowing Supremacy Clause claim to proceed alongside APA claim might "threaten[] to defeat the uniformity that Congress intended by centralizing administration of the federal program in the agency and to make superfluous or to undermine traditional APA review"); Mayo Found. for Med. Educ. and Research v. United States, 131 S. Ct. 704, 713 (2011) (applying Chevron deference to tax regulation).

210. See, e.g., Breger, supra note 196, at 344-46; Jeffrey S. Lubbers, APA-Adjudication: Is the Quest for Uniformity Faltering?, 10 ADMIN. L.J. AM. U. 65 (1996). The Environmental Protection Agency, for example, may impose some civil penalties without providing APA procedures. See William Funk, Close Enough for Government Work?-Using Informal Procedures for Imposing Administrative Penalties, 24 Seton Hall L. ReV. 1, 3-4 (1993).

211. See MASHAW, supra note 187, at 289. 
less publish, rules regarding their own organization or procedure, ${ }^{212}$ and few agencies did. ${ }^{213}$ The Attorney General's Committee recommended that information concerning agency organization, policy statements, statutory interpretations, substantive regulations, rules of procedure, forms, and instructions "be made available, in orderly and readily accessible form, to the public." ${ }^{214}$ Following through on that recommendation was one of the APA's "basic purposes." 115 Section 3(a) of the Act, now codified at 5 U.S.C. $\S 552$ (a), required agencies to state and publish descriptions of their organization, including delegations of final authority; "statements of the general course and method by which [their] functions are channeled and determined"; and substantive rules, policy statements, and interpretations. ${ }^{216}$ Rules of organization and procedure that are not published as required by section 3 are not binding. ${ }^{217}$ Thus, section 3 required agencies "to take the initiative in informing the public" about how they operate. ${ }^{218}$

Although agencies had become more proactive about publishing their rules as soon as the Attorney General's Committee issued its report, ${ }^{219}$ the requirements of section 3 were new. ${ }^{220}$ Members of Congress felt that they were "among the most important and useful provisions of the bill." ${ }^{221}$ Section 3 led agencies to assemble

212. Federal Register Act of 1935, Pub. L. No. 74-220, § 5(a), 49 Stat. 500, 501 (codified at 44 U.S.C. $§ 1505(\mathrm{a})(2)$ (2012)) (requiring publication of "documents or classes of documents that the President may determine from time to time have general applicability and legal effect"); see also AG's COMmitTEe RePORT, supra note 159, at 25-26, 225; David Reich, Administrative Procedure Act: Analysis of its Requirement as to Rule-Making, 33 A.B.A. J. 315, 316 (1947) [hereinafter Reich, Analysis]; David Reich, Rule Making Under the Administrative Procedure Act, in NYU Institute, supra note 193, at 495-96; Ashley Sellers, Administrative Procedure Act: Extent of Agency Compliance with Section 3, 33 A.B.A. J. 7, 7 (1947).

213. AG's COMMITTEE REPORT, supra note 159, at 26-27 (finding that few agencies issued "comprehensive or usable statements of their own internal organization," and although many agencies were issuing "directions as to practice and procedure ... [t]hey rarely outline[d] the whole process"); see also id. at 226 (highlighting that "not a single important agency now discloses in practical form its own internal organization and set-up").

214. Id. at 26 .

215. Clark, supra note 187, at 9; see also H.R. ReP. No. 79-1980 (1946), reprinted in LEGISLATIVE HisTORY, supra note 177, at 244-45.

216. Administrative Procedure Act, Pub. L. No. 79-404, § 3(a), 60 Stat. 237, 238 (1946) (codified as amended at 5 U.S.C. § 552(a)(1) (2012)); see also Sellers, supra note 212, at 8.

217. Administrative Procedure Act $\S 3(\mathrm{a}), 60$ Stat. 237, 238 ("No person shall in any manner be required to resort to organization or procedure not so published.").

218. H.R. REP. NO. 79-1980 (1946), reprinted in LEGISLATIVE HISTORY, supra note 177, at 235, 251; S. REP. No. 79-752 (1945), reprinted in LEGISLATIVE HistORY, supra note 177, at 187, 193.

219. See Nathanson, supra note 199 , at 378.

220. Pat McCarran, Improving “Administrative Justice”: Hearings and Evidence; Scope of Judicial Review, 32 A.B.A. J. 827, 830 (1946); see also Joanna Grisinger, Law in Action: The Attorney General's Committee on Administrative Procedure, 20 J. POL'Y \& HisT. 379, 406-07 (2008); Sellers, supra note 212, at 7; The Federal Administrative Procedure Act: Codification or Reform?, 56 YALE L.J. 670, 676, 687, 703 (1947).

221. 92 Cong. Rec. 5650 (1946) (statement of Rep. Francis Walter); see also H.R. ReP. No. 79-1980 (1946), reprinted in Legislative History, supra note 177, at 235, 255; S. ReP. No. 79-752 (1945), reprinted in Legislative History, supra note 177, at 187, 198. 
their rules in one place, analyze their practices, and state their requirements with more clarity and detail. 222 When section 3 became operative on September 11, 1946, the Federal Register swelled from its usual length of thirty to sixty pages to almost 1000 pages, despite the fact that many rules were not reprinted, but merely incorporated by reference to earlier publications. ${ }^{223}$ Thus, section 3's publication requirements altered regulatory baselines.

The APA's "most important reform" may have been notice and comment rulemaking. ${ }^{224}$ Before the APA, statutes generally did not specify rulemaking procedures or require notice to interested parties. ${ }^{225}$ Some agencies consulted with interested parties in rulemaking nonetheless. ${ }^{226}$ But there were a "multitudinous variety of procedures" for promulgating regulations with "no unifying principle." 227 The Attorney General's Committee majority aimed to improve rulemaking "by emphasizing the importance of outside participation" in the process, but thought that such consultation should not be statutorily mandated. ${ }^{228}$ The minority, on the other hand, included in its proposed bill a provision requiring agencies to provide notice and some opportunity for public comment. ${ }^{229}$ The APA followed the minority's

222. See Louis G. Caldwell, The Federal Communications Commission, in NYU Institute, supra note 193, at 91; Robert E. Freer, An Analysis of Federal Trade Commission Procedures as They Relate to the Administrative Procedure Act, in NYU InSTITUTE, supra note 193 , at 421.

223. Reich, Analysis, supra note 212, at 317; see also David Reich, Rule Making Under the Administrative Procedure Act, in NYU InstituTE, supra note 193, at 497; Sellers, supra note 212 , at 8 .

224. Shepherd, supra note 3, at 1583, 1635; see also, Present at the Creation: Regulatory Reform Before 1946, supra note 32, at 520.

225. See AG's Committee Report, supra note 159, at 102; Present at the Creation: Regulatory Reform Before 1946, supra note 32, at 520.

226. See AG's Committee Report, supra note 159, at 103; MASHAw, supra note 187, at 310 (noting that before the APA, some agencies informed the public of rules and guidelines and consulted with interested groups); see also CLARK, supra note 187, at 31 (explaining that federal agencies already "extensively employed" informal rulemaking procedures like "informal hearings (with or without a stenographic transcript), conferences, ... submission of written views"); Louis G. Caldwell, The Federal Communications Commission, in NYU INSTITUTE, supra note 193, at 94; Roger S. Foster, Application of the Administrative Procedure Act to the Statutes Administered by the Securities and Exchange Commission, in NYU InstituTE, supra note 193, at 214; W. Carroll Hunter, The Administrative Procedure Act in its Application to the Functions of the Department of Agriculture, in NYU InSTITUTE, supra note 193, at 377; Bradford Ross, Federal Power Commission Practice and Procedure as Affected by the Administrative Procedure Act of 1946, in NYU InSTITUTE, supra note 193, at 180; John H. Wanner, Effect of the Administrative Procedure Act upon the Civil Aeronautics Board, in NYU InSTITUTE, supra note 193, at 119.

227. Feller, supra note 160 , at 595. Although the case law at the time was similarly unsettled, Supreme Court decisions in the early 1940s suggested that "more procedural protection may need to be thrown around the rule-making process." C. Herman Pritchett, The Supreme Court and Administrative Regulation, 1941-1944, 31 IowA L. REV. 103, 111 (1945).

228. AG's COMMITTEE REPORT, supra note 159, at 6, 105.

229. Id. at 228. The minority's proposed bill left to agency discretion the choice of whether to proceed with written comments, conferences, informal hearings, or formal hearings. Id. at 228-29. 
recommendation. ${ }^{230}$ Section 4 of the Act, now codified at 5 U.S.C. $\S 553$, required agencies to publish in the Federal Register notice of proposed rulemakings and to "afford interested persons an opportunity to participate in the rule making."231 That requirement altered regulatory baselines. ${ }^{232}$

Another of the APA's reforms was section 5(c)'s requirement, now codified at 5 U.S.C. $\$ 554(\mathrm{~d})$, that agencies separate the functions of investigators and prosecutors from adjudicators. ${ }^{233}$ The Supreme Court observed in Wong Yang Sung v. McGrath that the APA arose from a concern that administrative adjudications could be biased and arbitrary. ${ }^{234}$ Merging functions created an "unwholesome atmosphere" for adjudicating private rights and "weaken[ed] public confidence" in the fairness of agency decision making. ${ }^{235}$ Before the APA, agencies varied in their adjudication procedures and internal structures. ${ }^{236}$ Some agencies began to shift toward greater separation of functions in response to the Attorney General's Committee's investigation. ${ }^{237}$ But the Committee was unanimous in its belief that "this evil" persisted. ${ }^{238}$ Section 5(c) of the APA allowed hearing officers to remain in their agencies, but required them be functionally independent of investigators and prosecutors. ${ }^{239}$ The Attorney General's Manual advised that officers who perform adjudicating functions should be housed in different units of agencies "to achieve fairness and independence in the hearing process." 240 Section 5(c) may have been "[o]ne of the most fundamental changes brought about by the Act." 241

230. Nathanson, supra note 199, at 382; see also Present at the Creation: Regulatory Reform Before 1946, supra note 32, at 514, 518, 520.

231. Administrative Procedure Act, Pub. L. No. 79-404, § 4(a)-(b), 60 Stat. 237, 239 (1946) (codified at 5 U.S.C. $§ 553$ (2012)); see also CLARK, supra note 187, at 26.

232. See The Federal Administrative Procedure Act: Codification or Reform?, supra note 220, at 675-76, 703; Ashley Sellers, "Informal" Dispositions Under the Administrative Procedure Act, 32 A.B.A. J. 646, 648 (1946) ("[A] statutory right and form of informal rule making procedure had to be largely invented ...."); Strauss, supra note 62, at 785; Present at the Creation: Regulatory Reform Before 1946, supra note 32, at 521 (stating that "notice and comment procedure, was original, not merely declaratory of what had already developed").

233. Administrative Procedure Act $\S 5$ (c) (codified at 5 U.S.C. $\S 554(d)$ (2012)).

234. 339 U.S. 33, 37-39 (1950).

235. Id. at 42 .

236. See AG's COMMITTEE REPORT, supra note 159, at 44-45; GRISINGER, supra note 188, at 69-70; Nathaniel L. Nathanson, Separation of Functions Within Federal Administrative Agencies: A Comment on the Report of the Attorney General's Committee on Administrative Procedure, 35 ILL. L. REv. 901, 907, 911-12, 915, 934 (1941).

237. See Nathanson, supra note 236, at 911-12, 915-16, 934.

238. Wong Yang Sung, 339 U.S. at 44; see also AG's COMMitTEE REPORT, supra note 159, at 45 ; Feller, supra note 160 , at 601.

239. Administrative Procedure Act, Pub. L. No. 79-404, § 5(c), 60 Stat. 237, 240 (1946) (codified at 5 U.S.C. $§ 554$ (2012)); see also H.R. REP. No. 79-1980 (1946), reprinted in LeGisLATIVE History, supra note 177, at 262; S. ReP. No. $79-752$ (1945), reprinted in LEGISLATIVE HistORY, supra note 177, at 203.

240. CLARK, supra note 187, at 54-56; see also Grisinger, supra note 220, at 405.

241. The Federal Administrative Procedure Act: Codification or Reform?, supra note 220, at 691, 703; see also Ashley Sellers, Adjudication by Federal Agencies Under the Administrative Procedure Act, in NYU InSTITUTE, supra note 193, at 529 (observing that the separation of functions requirement in $\S 5$ (c) was an "age-old maxim of good government," 
In the very least, the APA's passage meant that agencies were no longer guided solely by "common law standards, existing case law, and individual agency statutes." 242 As Jerry Mashaw observed, "A common law model based on private law traditions has been replaced by a regime of public law official accountability. This was and is a major revolution in our administrative constitution's vision of the relationship of administration to legal rights." ${ }^{243}$ In sum, while some of the APA codified existing law, many of its provisions established new law, thus demonstrating this characteristic of superstatutes.

\section{Passed the Test of Time}

The APA fits comfortably in the model of superstatutes insofar as it has passed the test of time. ${ }^{244}$ Many scholars have commented on the APA's endurance. ${ }^{245}$ Congress has reaffirmed and expanded the 1946 Act. Later Congresses advanced the enacting Congress's project of making agencies more transparent to the public ${ }^{246}$ by adding public information and open meeting requirements to section 3 of the Act. ${ }^{247}$ In 1976, Congress furthered the enacting Congress's goal of making hearing officers fair and independen $\mathrm{t}^{248}$ by adding a prohibition on ex parte communications in formal proceedings. ${ }^{249}$ The addition of a waiver of sovereign

but possibly a "brand-new law, for, curiously enough, court decisions recognizing the rule are surprisingly obscure").

242. Grisinger, supra note 220, at 408; see also Richard E. Levy \& Robert L. Glicksman, Agency-Specific Precedents, 89 TEX. L. REV. 499, 505 (2011) ("The APA transformed federal administrative law from a loose assortment of constitutional and common law doctrines into a body of law that centered on a single, overarching statute."); Carl McFarland, Analysis of the Federal Administrative Procedure Act, in NYU InSTITUTE, supra note 193, at 27 (stating that the significance of the APA is that "it is law; it must be obeyed"; the Act is "now the law of the land"); Schwartz, supra note 205, at 514 (opining that, although the APA was "not revolutionary," it was important insofar as it stated the essentials of administrative practice "in statutory form and impose[d] the best existing procedure upon the administrative process as a whole").

243. MASHAW, supra note 187 , at 315 . Mashaw continues by stating that "the revolution is incomplete" insofar as standing is denied to "beneficiaries of protective legislation" based on "a vision of negative liberty." Id.

244. See supra text accompanying notes 100, 103.

245. E.g., William H. Allen, The Durability of the Administrative Procedure Act, 72 VA. L. REv. 235, 237 (1986); Beermann \& Lawson, supra note 5, at 869 n.81; Levy \& Glicksman, supra note 242, at 508-09; Present at the Creation: Regulatory Reform Before 1946, supra note 32, at 510; Peter L. Strauss, Changing Times: The APA at Fifty, 63 U. CHI. L. REv. 1389, 1391 (1996); see also Craig N. Oren, Be Careful What You Wish For: Amending the Administrative Procedure Act, 56 ADMIN. L. REV. 1141, 1143 (2004) (arguing the APA has survived "because courts found ample flexibility in the APA's terms").

246. See supra note 216 and accompanying text.

247. Freedom of Information Act, ch. 324, § 3(a), 80 Stat. 250 (1966) (codified as amended at 5 U.S.C. $\S 552$ (2012)); Government in the Sunshine Act, Pub. L. No. 94-409, § 3(a), 90 Stat. 1241 (1976) (codified as amended at 5 U.S.C. § 552(b) (2012)).

248. See supra text accompanying notes 233-241.

249. Government in Sunshine Act $§ 4$ (codified at 5 U.S.C. $\S 557(d)$ (2012)). 
immunity to section 10 in $1976^{250}$ bolstered the enacting Congress's desire "to afford a remedy for every legal wrong." 251

Congress has also resisted efforts to upset the original legislative compromise by further restricting agencies. In the $1950 \mathrm{~s}$ and $60 \mathrm{~s}$, the ABA advanced proposals to, among other things, create a presumption in favor of formal rulemaking, conform the rules governing such proceedings to those of the federal courts, hinder agencies from overruling hearing examiners' decisions, and intensify judicial review. ${ }^{252}$ The "regulatory reform" efforts of the 1970s and 80s would have required de novo judicial review of all questions of law without deference and cost-benefit analysis of certain proposed rules. ${ }^{253}$ Cost-benefit analysis reappeared in the "Contract with America" in the mid-1990s. ${ }^{254}$ Current proposals would require formal rulemaking procedures and congressional approval for rules that would have a significant economic impact. ${ }^{255}$ These efforts to rebalance the agreement codified in the 1946 Act have spurred "prolonged and serious" debate ${ }^{256}$ and generated congressional reports and hearing transcripts far too numerous to list here. ${ }^{257}$ To date, however, all of these efforts have failed. ${ }^{258}$

\section{Affected the Law Broadly}

The APA has had a strong gravitational pull on the law, influencing the design and interpretation of other statutes and the Constitution itself. ${ }^{259}$ The Act has had

250. Act of Oct. 21, 1976, ch. 7, sec. 702-03, 90 Stat. 2721, 2721, (codified at 5 U.S.C. $\S 702(2012))$.

251. H.R. ReP. No. 79-1980 (1946), reprinted in LEGISLATIVE HistoRy, supra note 177, at 251; S. ReP. No. 79-752 (1945), reprinted in LEGISLATIVE HiSTORY, supra note 177, at 193.

252. See Allen, supra note 245, at 238, 241-42; Breger, supra note 196, at 340-41; Ronald M. Levin, Statutory Reform of the Administrative Process: The American Experience and the Role of the Bar, 83 WASH. U. L.Q. 1875, 1880 (2005); Oren, supra note 245, at 1149-50.

253. Allen, supra note 245, at 240; Breger, supra note 196, at 342; Levin, supra note 252, at 1884-87; Oren, supra note 245, at 1153; see also Ronald M. Levin, Comment, Review of "Jurisdictional" Issues Under the Bumpers Amendment [hereinafter Levin, Review], 1983 Duke L.J. 355; James T. O'Reilly, Deference Makes a Difference: A Study of Impacts of the Bumpers Judicial Review Amendment, 49 U. CIN. L. REV. 739 (1980).

254. Oren, supra note 245, at 1153-54; see also Levin, supra note 252, at 1887.

255. See Regulatory Accountability Act of 2013, H.R. 2122, 113th Cong. (2013); Regulations from the Executive in Need of Scrutiny Act of 2013, H.R. 367, 113th Cong. (2013).

256. Breger, supra note 196, at 340.

257. E.g., Regulatory Reform Act-S. 1080: Hearing Before the Subcomm. on Regulatory Reform of the S. Comm. on the Judiciary, 97th Cong. (1981); H.R. REP. No. 113-160 (2013); H.R. REP. No. 112-294 (2011); S. REP. No. 104-89, at 4-5 (1995) (summarizing committee's study of regulatory reform "for over two decades"); S. REP. No. 97-284, at 1-2 (1981) ("S. 1080 , the Regulatory Reform Act, is the most recent product of at least seventeen years of work in the Senate on improving the process by which federal regulations are promulgated and enforced.").

258. See Levin, supra note 252, at 1881 ("The judgment of history has been that the 1946 APA reached a basically sound reconciliation of competing considerations . ...").

259. See supra text accompanying notes 74-76, 101-102, 112. 
"colonizing effects on other statutes." 260 The APA's requirement for public notice and comment in rulemaking, for example, is repeated throughout the U.S. Code, ${ }^{261}$ as is the arbitrary or capricious standard. ${ }^{262}$ The Act also has guided the courts' interpretation of other statutes. For instance, the D.C. Circuit has long turned to APA case law when applying the arbitrary or capricious standard in the Surface Mining Control and Reclamation Act. ${ }^{263}$

More importantly, the APA has taken on the normative gravity that characterizes a superstatute. ${ }^{264}$ Gillian Metzger demonstrated that constitutional values infuse administrative law and, conversely, "ordinary administrative schemes and requirements ... can inform judicial understandings of what the Constitution requires. ${ }^{265}$ Due process provides an apt example. The loyalty boards of the late 1940s led to the D.C. Circuit's holding in Bailey v. Richardson that due process did not protect a federal employee who was fired for being disloyal because she had no property interest in her employment. ${ }^{266}$ Even if she had a property interest, the court continued, due process would not entitle her to "specificity in charges equivalent to that of valid criminal charges, confrontation by witnesses, cross examination of them, and hearing upon evidence openly submitted." ${ }^{267}$ That state of affairs did not last long. As Joanna Grisinger observed, "the APA's clear statement of administrative norms - some of which exceeded constitutional requirements-gave American lawyers a yardstick against which to measure the procedures of the loyalty program." 268 If it applied in Bailey's case, the APA would have required the procedures she desired, ${ }^{269}$ and the Act soon became "a standard of due process

260. Eskridge \& Ferejohn, Super-Statutes, supra note 9, at 1235. On the extent to which the federal APA has colonized state APAs, see generally MiCHAEL AsimOW \& RonALD M. Levin, State and Federal Administrative Law (3d ed. 2009); Arthur Earl Bonfield, The Federal APA and State Administrative Law, 72 VA. L. REV. 297 (1986).

261. See, e.g., 8 U.S.C. § 1356(h)(1) (2012); 12 U.S.C. $§ 2279 \mathrm{bb}-1(\mathrm{~d})(1)(2012) ; 15$ U.S.C. $\S 7214(\mathrm{a})(2)(\mathrm{C})(2012) ; 16$ U.S.C. $\S 1383 \mathrm{~b}(\mathrm{a})(1)(2012) ; 18$ U.S.C. $\S 1520(\mathrm{a})(2)(2012) ; 25$ U.S.C. $\S 458 c(b)(2012) ; 42$ U.S.C. $\S 7607(d)(3)(2012)$.

262. See, e.g., 5 U.S.C. $\S 7703(c)(1)(2012) ; 8$ U.S.C. $\S 1189(c)(3)(A) ; 30$ U.S.C. $\S 1276(\mathrm{a})(1)(2012) ; 31$ U.S.C. $\S 755(\mathrm{a})(1)$ (2012); 38 U.S.C. $\S 7261(\mathrm{a})(3)$ (2012); 42 U.S.C. $\S 7607(d)(9)(a)$ (2012); 42 U.S.C. § 9613(j)(2) (2012).

263. See Nat'l Mining Ass'n v. Kempthorne, 512 F.3d 702, 710 n.4 (D.C. Cir. 2008); In re Surface Mining Regulation Litig., 627 F.2d 1346, 1360 (D.C. Cir. 1980).

264. ESKRIDGE \& FEREJOHN, REPUBLIC, supra note 9, at 27.

265. Metzger, supra note 24, at 484-85, 507; see also Edward L. Rubin, How Statutes Interpret the Constitution, 120 YALE L.J. ONLINE 297 (2011), http://www.yalelawjournal.org /forum/how-statutes-interpret-the-constitution (arguing that superstatutes are interpretations of the Constitution itself).

266. 182 F.2d 46, 57 (D.C. Cir. 1950), aff'd by an equally divided court, 341 U.S. 918 (1951) (per curiam).

267. Id. at 59 .

268. GRISINGER, supra note 188 , at 107.

269. 5 U.S.C. $§ 554($ b) (2012) (requiring notice of "the matters of fact and law asserted"); id. $\S 556$ (d) ("A party is entitled to . . . such cross-examination as may be required for a full and true disclosure of the facts"); $i d . \S 556(\mathrm{e})$ ("The transcript of testimony and exhibits ... constitutes the exclusive record for decision ... and ... shall be made available to the parties"); see also id. §554(a)(2) (exempting "the selection or tenure of an employee" from the APA's 
against which other government procedures might struggle to be justified." ${ }^{270}$ By 1961, the Supreme Court had changed course and held that what procedures due process requires turns on the "nature of the government function involved" and the "private interest that has been affected by governmental action."271

In sum, the APA bears all the hallmarks of a superstatute.

\section{IMPLICATIONS FOR THE APA'S INTERPRETATION}

Eskridge and Ferejohn contend that superstatutes are and should be interpreted broadly and evolutively, potentially exceeding congressional intent. ${ }^{272}$ That contention, however, is premised on a public deliberative process that the APA does not follow. Eskridge and Ferejohn did not discuss superstatutes like the APA whose interpretation Congress did not delegate to any particular agency. Nonetheless, their work indicates that courts should hesitate before stretching the terms of the APA. Instead, courts should focus their review on the history of the Act, both before and after its enactment, paying particular attention to the legislative compromises encoded in the Act and any public deliberation it has encountered since 1946.

Applying superstatute theory to the APA does more than demonstrate why stretching the statute's terms is problematic, however; it also shows why administrative common law that contradicts or ignores the APA is particularly troubling. The problem with administrative common law is not just that common law is created by countermajoritarian courts; the problem is that, unlike other statutes, there is no agency that administers the APA and engages in an ongoing dialogue with the President, Congress, the courts, and the public. Thus, even if administrative common law can satisfy separation-of-powers and political-accountability concerns, it still raises public deliberation concerns.

\section{A. The Role of Deliberation in Superstatute Theory}

What legitimizes interpreting superstatutes so that they evolve over time, even to the point of exceeding the enacting Congress's expectations? Deliberation. In superstatute theory, deliberation not only leads to entrenchment (that is, it makes some statutes super), but it also legitimizes evolutive interpretation of superstatutes. Eskridge and Ferejohn propound a civic-republican model of deliberation that requires feedback from the public. ${ }^{273}$ Sometimes the public gives feedback in elections. For example, Eskridge and Ferejohn assert that the election of national leaders who endorsed the Justice Department's interpretation of the Sherman Act legitimized the Department's departure from Congress's original statutory intent. ${ }^{274}$

adjudication provisions).

270. GRISINGER, supra note 188, at 107; see also Reuel E. Schiller, Enlarging the Administrative Polity: Administrative Law and the Changing Definition of Pluralism, 1945-1970, 53 VAND. L. REV. 1389, 1429 (2000) ("The demise of the rights/privileges distinction resulted from the rise of the participatory ideal of policy making.").

271. Cafeteria \& Rest. Workers Union, Local 473 v. McElroy, 367 U.S. 886, 895 (1961).

272. See supra Part II.B.

273. E.g., ESKRIDGE \& FEREJOHN, REPUBLIC, supra note 9, at 78.

274. See id. at 162-63. 
The state statutory convergence of married women's property laws arose through "legislatures directly accountable to citizens." 275

Even without direct public involvement, however, Eskridge and Ferejohn assert that superstatutory evolution is legitimate if the interpretive exercise is connected to the public through an implementing agency. Congress must have delegated interpretive authority to the agency: "When Congress adopts an ambitious statute and delegates enforcement authority (as it must) to executive and judicial officers, Congress ought to expect a dynamic application of the statute . .." ${ }^{276}$ But that delegation, standing alone, is not sufficient to justify agency-led interpretive evolution of superstatutes. The best way to legitimize an agency's dynamic interpretation, Eskridge and Ferejohn say, is congressional ratification, such as Congress's endorsement of the Interior Department's interpretation of the Endangered Species Act in the 1982 amendments. ${ }^{277}$ In the absence of ratification, the agency bears a greater burden of securing "grassroots support from some other source, including direct appeals to We the People, Ourselves." ${ }^{278}$ Ultimately, "public deliberation" is "the most plausible mechanism for legitimating dynamic agency interpretations." 279

"Deliberation" in superstatute theory typically involves agency implementation and public input in a feedback loop. ${ }^{280}$ First the legislature, responding to popular will, enacts a statute and delegates its implementation to an agency. The agency plays a "primary role," "work[ing] with affected groups to devise a workable implementation." 281 The public makes its views known to Congress and to the agency. ${ }^{282}$ Within the agency, the ideal model for public feedback is rulemaking, in which the agency gives public notice of its proposal, receives and seriously considers public comments, and publishes an explanation for its decision that is "cogently tied to congressional purposes." 283 Finally, "legislators reaffirm and expand upon the

275. Id. at 213; see also id. at 225, 238.

276. Id. at 160; see also id. at 269 (arguing Congress's delegation of authority to agencies to interpret a broad statutory term made the agencies' "purposive expansion of the statute beyond, and probably against, original congressional expectations ... not only likely but also legitimate"). Expansive application of the Clean Water Act was legitimate because Congress delegated to EPA and the Corps authority to interpret the statute's broad terms. Id. at 269.

277. Id. at $274,297$.

278. Id. at 264; see also id. at 289 (arguing dynamic interpretation of superstatutes "ought to be publicly justified and debated, at least through agency rule making and perhaps through formal congressional action").

279. Id. at 161 .

280. See id. at $19,105$.

281. Id. at 23, 26; see also Stephen M. Griffin, The National Security Constitution and the Bush Administration, 120 YALE L.J. ONLINE 367 (2011), http://www.yalelawjournal.org /forum/the-national-security-constitution-and-the-bush-administration (observing that Eskridge and Ferejohn's model of administrative constitutionalism "does not appear to allow for" the possibility that the President could initiate small "c" constitutional change via, for example, the Commander-in-Chief power).

282. ESKRIDGE \& FEREJOHN, REPUBLIC, supra note 9, at 23, 26.

283. Eskridge, America's Statutory “constitution," supra note 9, at 37; see also infra text accompanying note 368. Agencies may trigger public feedback in other ways. The Justice Department's interpretation of the Sherman Act, for example, has been propounded and debated in amicus briefs, law review articles, empirical studies, policy papers, and 
statutory scheme." 284 This model of deliberation incorporates administrative-law values like public participation, reason-giving, and transparency; central to this model is "feedback" directly from "We the People," as well as from experts, regulated entities, and critics. ${ }^{285}$

Eskridge and Ferejohn argue that this type of agency-centered deliberation has "dual virtues": it improves the quality of public policy and provides legitimacy. ${ }^{286}$ For deliberation to have "legitimating value," it must have three "key features." 287 First, it must respond to both the deep and the urgent needs of "We the People."288 Second, it must continue with executive agencies typically taking the lead and Congress and the courts providing input. ${ }^{289} \mathrm{Third}$, it requires "feedback from outside the government." ${ }^{.90}$ It is the "strong connection to the people and popular needs" that legitimizes evolutive interpretation of superstatutes. ${ }^{291}$ Eskridge and Ferejohn

"presidential jawboning that the American consumer paid lower prices because government policy was protecting, but not overprotecting, the free market." ESKRIDGE \& FEREJOHN, REPUBLIC, supra note 9, at 158.

284. ESKRIDGE \& FEREJOHN, RePUBLIC, supra note 9, at 23; see also id. at 14. A classic example of this feedback loop is the Endangered Species Act. Endangered Species Act of 1973, Pub. L. No. 93-205, 87 Stat. 884 (codified at 16 U.S.C. 1531 (2012)). Congress delegated to the Department of the Interior the authority to interpret the Act. The Department issued a regulation interpreting the Act's ban on "harming" listed species as including destruction of the species' habitat. 50 C.F.R. $\S 17.3$ (2015). When Congress amended the Act in 1982, it ratified that broad interpretation. Endangered Soecies Act Amendments of 1982, Pub. L. No. 97-304, 96 Statl 1411 (codified at 16 U.S.C. § 1539(a); see also id. at 274, 296-97.

285. Id. at 78 (emphasis in original). The judiciary also plays a role in integrating the statute "into the nation's other normative commitments" and monitoring agencies. Id. Emily Hammond points out that agencies and courts engage in dialogue, particularly in the course of serial litigation. Emily Hammond Meazell, Deference and Dialogue in Administrative Law, 111 Colum. L. Rev. 1722 (2011). See generally Emily Hammond Meazell, Dialogue, Deferred and Differentiated, 112 Colum. L. REV. SideBAR 185 (2012). Gluck and Bressman's recent empirical research, however, throws into doubt the traditional assumption that the courts and Congress communicate with each other effectively. See Bressman \& Gluck, Part II, supra note 42, at 765-77. Instead, Gluck and Bressman "paint a picture of legislative staffers in a primary interpretive conversation with agencies, not with courts." Id. at 728 (emphasis in original); see also id. at 765, 767, 776-77.

286. ESKRIDGE \& FEREJOHN, REPUBLIC, supra note 9, at 158; see also id. at 27, 103. In construing deliberation as "a means by which opponents are brought around to agreement," Eskridge and Ferejohn go beyond "the modern normative literature of deliberation" to "something more nuanced and novel." McCubbins \& Rodriguez, supra note 9, at 389-90. In conceiving of deliberation as a means of improving the quality of public policy, Eskridge and Ferejohn answered Lisa Schultz Bressman's call for scholarship that treats prevention of arbitrary agency action as central to both "good regulatory government" and "legitimate regulatory government." Lisa Schultz Bressman, Beyond Accountability: Arbitrariness and Legitimacy in the Administrative State, 78 N.Y.U. L. REV. 461, 494 (2003) (emphasis in original).

287. See Eskridge \& Ferejohn, Republic, supra note 9, at 27, 103-04 (emphasis in original).

288. Id. at 103 .

289. Id. at $103-04$.

290. Id. at 104.

291. Eskridge \& Ferejohn, Super-Statutes, supra note 9, at 1276; see also Griffin, supra 
propound a "broadly ambitious notion of deliberation" as "a mechanism of sharing assumptions, debating basic norms, grappling with matters of implementation, and changing hearts and minds." 292

Eskridge and Ferejohn's entire theory is built on the normative superiority of deliberation that involves the public and representative branches of government rather than just the parties to a particular case and unelected judges. The process by which a statute becomes entrenched and that justifies evolutive interpretation of superstatutes involves Congress, agencies, and the public coming to a consensus, not simply the courts making pronouncements. The version of republican deliberation Eskridge and Ferejohn espouse is "accountable to stakeholders"; that accountability is strongest for members of the House of Representatives and weakest for judges who "do not face the voters at all." 293 Thus, although many administrative common law doctrines reflect ongoing dialogue between the federal courts (particularly the D.C.

note 281, at 384 (explaining that superstatute theory "depend[s] upon extensive public deliberation to ensure that the constitutional changes that [it] describe[s] are accepted as authoritative"). Scholars have questioned the value of administrative deliberation generally. See, e.g., Thomas O. McGarity, Administrative Law as Blood Sport: Policy Erosion in a Highly Partisan Age, 61 Duke L.J. 1671, 1703-19 (2012); Mark Seidenfeld, The Role of Politics in a Deliberative Model of the Administrative State, 81 GEO. WASH. L. REV. 1397, 1426-35, 1444 (2013) [hereinafter Seidenfeld, The Role of Politics]; Jonathan Weinberg, The Right To Be Taken Seriously, 67 U. Miami L. Rev. 149, 178-90 (2012). But see Mark Seidenfeld, A Civic Republican Justification for the Bureaucratic State, 105 HARV. L. REV. 1511 (1992) [hereinafter Seidenfeld, Civic Republican Justification] (arguing that civic republican theory justifies giving agencies broad policymaking authority and that agencies are the best hope for achieving the civic republican deliberative government ideal); Seidenfeld, The Role of Politics, supra, at 1445-57 (endorsing agency staff-based deliberation coupled with judicial review). If administrative deliberation generally falls short of superstatute theory's ideal, then Eskridge and Ferejohn's reliance on it may be unjustified. That inquiry is beyond the scope of this Article.

292. McCubbins \& Rodriguez, supra note 9, at 394. McCubbins and Rodriguez protest that that kind of deliberation only exists in rare circumstances and, generally, deliberation merely yields compromise. Id. at 390-94; see also Mathew D. McCubbins \& Daniel B. Rodriguez, When Does Deliberating Improve Decisionmaking?, 15 J. ConTEMP. LeGAL Issues 9 (2006). The evolutive administrative interpretation of superstatutes that Eskridge and Ferejohn advocate, however, may undermine compromises that emerged from the original deliberative legislative process and that became encoded in the superstatute itself. Hence, there is a fundamental tension between entrenchment through deliberation and dynamic agency interpretation over time. McCubbins \& Rodriguez, supra note 9, at 395-97. McCubbins and Rodriguez suggest that that tension can be resolved either by viewing agency discretion as inevitable given "the need for flexibility" in public policy or by recognizing that Congress designs superstatutes to enable that sort of administrative updating. Id. at 397-98. Eskridge and Ferejohn espouse both resolutions. They clearly see broad administrative discretion in implementing superstatutes as necessary and inevitable, but their underlying assumption is that Congress has delegated to the agency the authority to issue binding interpretations of the superstatute. See supra text accompanying notes 276, 281-283. Professor Eskridge made this point more explicitly in prior work. ESKRIDGE, supra note 134, at 112-16; see also William N. Eskridge, Jr., Vetogates, Chevron, Preemption, 83 Notre Dame L. ReV. 1441, 1457 (2008) [hereinafter Eskridge, Vetogates].

293. See ESKRIDGE \& FEREJOHn, Republic, supra note 9, at 15 (emphasis omitted). 
Circuit ${ }^{294}$ ) and the legal community, that sort of engagement does not satisfy Eskridge and Ferejohn's call for a civic-republican type of deliberation that engages the public.

This aspect of superstatute theory has a long pedigree. "In its most general form, the demand for deliberation has been a familiar theme in the American constitutional tradition. It is integral to the ideal of republican government as the Founders understood it." ${ }^{295}$ More recently, Jeremy Waldron explained why judicial deliberation falls short of the republican ideal. He asserted that political disagreement is inevitable. Thus, for a decision to be authoritative, it is not sufficient for the decision to be "right." Instead, the decision must result from a fair process. ${ }^{296}$ Majority rule inevitably leaves some people subject to laws they think are unjust, but it is fair insofar as it gives "equal weight to each person's view." ${ }^{297}$ Courts also reach results some people believe are unjust, but they have

one legitimacy-related defect that popular majoritarianism does not have: they do not allow a voice and a vote in a final decision-procedure to every citizen of the society; instead they proceed to make final decisions about the rights of millions on the basis of the voices and votes of a few. ${ }^{298}$

Thus, Waldron called it "something of an insult" to relegate the resolution of disagreements to a handful of judges who, like a legislature, will often disagree among themselves and, like a legislature, will resolve their own disagreements by a majority vote. ${ }^{299}$ If disagreements are to be settled by "counting heads," then it should be the heads of the citizens' accountable representatives that are counted. ${ }^{300}$

Amy Gutmann and Dennis Thompson also question the superiority of judicial deliberation. That supposed superiority is premised on the assumptions that legislators, because they must stand for election, will necessarily reflect the preferences of their constituents, while judges "will have more regard for well-reasoned principles." ${ }^{301}$ Gutmann and Thompson challenge those assumptions, pointing out that because legislators "must defend their policies to many different groups," they are "forced to formulate generally acceptable policies, and justify them by general principles." 302 Judges, in contrast, decide particular cases, hearing only from the citizens that appear as parties to the case and thus often pronounce narrow principles without considering the "larger social implications of their decisions." 303

294. The D.C. Circuit is "the nation's premier administrative law court," Jean Galbraith \& David Zaring, Soft Law as Foreign Relations Law, 99 Cornell L. Rev. 735, 758 (2014), because it has exclusive jurisdiction over many administrative law matters and concurrent jurisdiction over most others. See John G. Roberts, Jr., What Makes the D.C. Circuit Different? A Historical View, 92 VA. L. ReV. 375, 389 (2006).

295. Amy Gutmann \& Dennis Thompson, Democracy and Disagreement 12 (1996).

296. See Jeremy Waldron, Law And DisagreEment 213, 253 (1999).

297. Id. at 114 (emphasis in original); see also id. at 247.

298. Id. at 299.

299. Id. at 15 .

300. Id. at 15, 90-91; see also Jeremy WALDRON, The Dignity of Legislation 126-29 (1999).

301. GUTMANN \& THOMPSON, supra note 295 , at 45 .

302. Id.

303. Id. 
Mark Seidenfeld agrees that courts are "necessarily reactive," are not "designed to develop a consensus about the public good," and "are too far removed from the voice of the citizenry" to ensure that their policies will be generally acceptable. ${ }^{304}$

Eskridge and Ferejohn echo these refrains. To them, the Supreme Court is not an "exemplary deliberative body." ${ }^{305}$ Judicial deliberation "values detachment from politics, principled reasoning from uncontested premises, and case-by-case incrementalism." In a democracy, however, "deliberation should be politically engaged as well as rational, should be forward-looking and openly normative as well as principled, and should engage in wholesale and not just retail rule making." ${ }^{306}$ Judicial review's proper role is in checking interpretations that exceed legislative authorizations or "fall athwart larger normative commitments." ${ }^{307}$ It is not the role of the courts to ignore or countermand the results of republican deliberation.

\section{B. The Lack of Agency-Centered Deliberation in the APA}

Although the APA is an entrenched superstatute, it does not have the same lifecycle as other superstatutes. Perhaps the closest analogies Eskridge and Ferejohn discuss are the state statutory convergences in the family law arena. Like the APA, the married women's property laws and no-fault divorce laws became entrenched without a single agency at the center of the interpretive universe. But that analogy does not justify evolutive interpretation of the APA "beyond and even against the original congressional expectations." ${ }^{308}$ In their chapter from A Republic of Statutes discussing state family law, Eskridge and Ferejohn do not allege that the individual state statutes that make up a superstatutory convergence should be interpreted evolutively; rather they focus on the process by which the norm in a series of similar state statutes can become entrenched through state legislative action and periodic elections, ultimately leading to a convergence across states. ${ }^{309}$ The connection to the public in that model is through elections. Similarly, Eskridge and Ferejohn assert that the election of national leaders who endorsed the Justice Department's new, evolutive interpretation of the Sherman Act justified exceeding the enacting Congress's intent. ${ }^{310}$ Unlike the state family law convergences and the Sherman Act,

304. Seidenfeld, Civic Republican Justification, supra note 291, at 1542-43.

305. ESKRIDGE \& FEREJOHN, REPUBLIC, supra note 9, at 21.

306. Id.

307. Id. at 24; see also William N. Eskridge, Jr., Expanding Chevron's Domain: A Comparative Institutional Analysis of the Relative Competence of Courts and Agencies To Interpret Statutes, 2013 WISC. L. REV. 411 (2013) (arguing that agencies are superior to courts in statutory interpretation, but courts play an important role in monitoring agency dysfunction).

308. ESKRIDGE \& FEREJOHN, REPUBLIC, supra note 9, at 263, 267.

309. See id. at $213,225,238$. This focus is not surprising, since superstatute theory is primarily a theory of small "c" constitutional change.

310. Id. at 162-63. "The primary purpose of antitrust law has changed in the past century - from protection of diffused industry structures and of small competitors . . . to maximization of consumer welfare, with tolerance for a great deal of market concentration." Id. at 121 (emphasis in original). That evolution of the Sherman Act was justified not only because the public endorsed it in national elections, but also because "Americans have voted with their feet on the issue of localism versus lower prices," opting for Lowe's and Home Depot instead of "the local hardware store." Id. at 163. 
however, elections have not endorsed the courts' evolutive, common law expansion of the APA beyond the boundaries of the text and contrary to Congress's intent. ${ }^{311}$

Superstatute theory typically depends on an agency-centered deliberative feedback loop to justify evolutive interpretation of federal superstatutes. Unlike the typical superstatute, however, the APA is not administered by a single agency. Congress did not vest any single agency with the power to interpret the statute in rules or orders. ${ }^{312}$ It did not anticipate that the statute would be updated administratively. To the contrary, Congress anticipated that it would have to update the statute itself. ${ }^{313}$ Certainly, federal agencies interpret the APA. All federal agencies do so as they go about their regulatory business; the Justice Department does so in litigation; the Office of Information and Regulatory Affairs (OIRA) in the Office of Management and Budget does so in the course of reviewing agencies' regulatory proposals; and the Administrative Conference of the United States (ACUS) does so as it studies federal administrative procedure. But none of those activities results from a congressional delegation of interpretive authority as it must to justify evolutive interpretation, ${ }^{314}$ and only ACUS arguably meets superstatute theory's other deliberative demands. Thus, in the case of the APA, agencies are not at the center of the deliberative universe; courts are, and courts do not engage in the civic-republican style of deliberation that superstatute theory demands. Therefore, that model of deliberation does not legitimize evolutive interpretation of the APA.

311. The Sherman Act is also distinguishable from the APA because it is administered by its "primary enforcement agent," the Department of Justice. See id. at 127; see also id. at 134, 140 41, 153-57. Moreover, the Supreme Court has held that Congress did not intend for the Sherman Act to halt the development of antitrust common law. Lemos, supra note 186, at 429, 461-63.

312. See Linda D. Jellum, The United States Court of Appeals for Veterans Claims: Has It Mastered Chevron's Step Zero?, 3 VetERANS L. REV. 67 (2011). This lack of single-agency administration sets the APA apart from the National Environmental Policy Act (NEPA), 43 U.S.C. $\S \S 4321-4370(h)$ (2012), another obvious candidate for superstatute status. Like the APA, NEPA is not administered by a single agency. Unlike the APA, a particular agency, the Council on Environmental Quality (CEQ), interprets NEPA in regulations. "NEPA established CEQ to assist and advise the President on environmental policy, and a 1977 Executive Order charged CEQ with issuing regulations to federal agencies for implementation of NEPA's procedural provisions," and the Court gives CEQ's regulations "substantial deference." Winter v. NRDC, 555 U.S. 7, 50 (2008) (Ginsburg, J., dissenting) (citations omitted); see also Robertson v. Methow Valley Citizens Council, 490 U.S. 332, 355 (1989). But see Richard Lazarus, The National Environmental Policy Act in the U.S. Supreme Court: A Reappraisal and a Peek Behind the Curtains, 100 Geo. L.J. 1507, 1563 (2012) (pointing out that questions at the oral argument in Winter indicated that "the Justices may harbor some significant doubts about [CEQ's] legitimacy").

313. S. ReP. No. 79-752 (1945), reprinted in LEGISLATIVE History, supra note 177, at 187, 216-17. The House ended its report saying: "This bill is not, of course, the final word. It is a beginning. If it becomes law, changes may be made in the light of further experience; and additions should be made." H.R. REP. NO. 79-1980 (1946), reprinted in LEGISLATIVE HISTORY, supra note 177 , at $235,282$.

314. See supra text accompanying note 276. 


\section{All Agencies}

Each federal agency must interpret the APA in the course of its operations, and many agencies issue regulations doing so. For example, the Director of the Federal Register has issued regulations interpreting section 552(a)'s provision for publication by reference, which requires his approval. ${ }^{315}$ The FAA's regulations interpret the APA's rulemaking provisions. ${ }^{316}$ The Department of Labor's regulations interpret the adjudication provisions. ${ }^{317}$ And the Department of Health and Human Service's regulations explain when a hearing examiner's decision becomes "final agency action" under the APA. ${ }^{318}$

None of those interpretations, however, results from statutory authorization to interpret the APA itself, none is binding on any other agency, and none is entitled to deference. ${ }^{319}$ In declining to defer to agency interpretations of the APA, courts have reasoned that the APA is not within any particular agency's expertise, and no agency has been charged with its administration. ${ }^{320}$ Thus, Congress has no reason "to expect a dynamic application of the statute." 321 In addition, if multiple agencies interpret the same statute, consistency in their interpretations is far from assured. ${ }^{322}$

By the same token, agency interpretations of the APA are too diffuse to meet superstatute theory's demand for public deliberation. In a "model deliberation," the agency "considers inputs from a variety of sources" and "accommodates larger public norms. ${ }^{\prime 323}$ But the APA's effect on the public is indirect. Thus, one wouldn't expect the general public to be aware of, much less participate in, for example, the FAA's development of regulations governing how it develops regulations. Certainly

315. See 5 U.S.C. $\S 552(a)$ (2012); 1 C.F.R. $§ 51.1$ (2014).

316. See 5 U.S.C. $\S 553$ (2012); 14 C.F.R. $\S \S 11.1-11.101$ (2014).

317. See 5 U.S.C. $\S \S 554,556-557$ (2012); 29 C.F.R. $\S \S 18.1-18.31$ (2014).

318. See 5 U.S.C. $\S 704$ (2012); 45 C.F.R. $\S 81.104$ (2014).

319. See Jellum, supra note 312.

320. Metro. Stevedore Co. v. Rambo, 521 U.S. 121, 137 n.9 (1997) (holding Director of the Office of Workers' Compensation Programs' interpretation of APA was not entitled to Chevron deference in part because the APA "is not a statute that the Director is charged with administering”); Prof'1 Reactor Operator Soc'y v. NRC, 939 F.2d 1047, 1051 (D.C. Cir. 1991) (" $[R]$ eviewing courts do not owe the same deference to an agency's interpretation of statutes that, like the APA, are outside the agency's particular expertise and special charge to administer.”); Air N. Am. v. Dep't of Transp., 937 F.2d 1427, 1436-37 (9th Cir. 1991); Cass R. Sunstein, Chevron Step Zero, 92 VA. L. REv. 187, 209 (2006); see also Bowen v. Am. Hosp. Ass'n, 476 U.S. 610, 642 n.30 (1986) (explaining that where multiple agencies promulgated regulations interpreting the Rehabilitation Act, " $[\mathrm{t}]$ here is . . not the same basis for deference predicated on expertise").

321. See ESKRIDGE \& FEREJohn, Republic, supra note 9, at 160; see also id. at 269.

322. Collins v. Nat'l Transp. Safety Bd., 351 F.3d 1246, 1252-53 (D.C. Cir. 2003) ("Where a statute is generic, two bases for the Chevron presumption of implied delegation are lacking: specialized agency expertise and the greater likelihood of achieving a unified view through the agency than through review in multiple courts."); Rapaport v. Dep't of Treasury, 59 F.3d 212, 216-17 (D.C. Cir. 1995) ("The alternative would lay the groundwork for a regulatory regime in which either the same statute is interpreted differently by the several agencies or the one agency that happens to reach the courthouse first is allowed to fix the meaning of the text for all.").

323. ESKRIDGE \& FEREJOHN, REPUBLIC, supra note 9, at 265. 
stakeholders will take notice and the public will too on some occasions, such as when an agency decides its action falls within an exception to section 553's rulemaking requirements. Typically, however, when agencies interpret the APA in the normal course of business, the public input will lack the "strong connection to the people and popular needs" that superstatute theory requires to legitimize evolutive agency interpretation. ${ }^{324}$

\section{The Department of Justice}

The most authoritative executive branch interpretations of the APA come from the Justice Department in litigation and particularly from the Office of the Solicitor General in the Supreme Court. While Congress has authorized the Attorney General to represent the United States in court, ${ }^{325}$ it has not authorized him to issue binding interpretations of the APA and thus has no reason to expect the Act to evolve at his hands. ${ }^{326}$ In addition, although the Justice Department certainly deliberates carefully about the positions it takes in litigation, and often reconciles multiple agency viewpoints, that process is not the sort of civic republican deliberation that is central to Eskridge and Ferejohn's contention that superstatutes should evolve common-law style. ${ }^{327}$ The give-and-take between the executive and judicial branches in litigation is largely deaf to the public's voice. ${ }^{328}$

\section{The Office of Information and Regulatory Affairs (OIRA)}

OIRA fosters significant deliberation in the development of regulations. ${ }^{329}$ Since the Reagan administration, executive orders have charged OIRA, which is part of the Executive Office of the President, with reviewing certain regulatory actions. ${ }^{330}$ OIRA

324. See Eskridge \& Ferejohn, Super-Statutes, supra note 9, at 1276.

325. 28 U.S.C. $\$ 516$ (2012).

326. See supra text accompanying note 276.

327. See Eskridge \& Ferejohn, Republic, supra note 9, at 27 ("[W]e have a dynamic, problem-solving, and republican understanding of deliberation."); see also id. at 21 (noting that the title of the book "mobilizes not only the interactive, forward-looking understanding of deliberation suggested here, but also the classic republican notion of citizens and public leaders acting for the common good"). The lack of republican deliberation may explain Eskridge and Ferejohn's assertion that "deference is not appropriate for agency litigating positions.” Eskridge \& Ferejohn, Super-Statutes, supra note 9, at 1252.

328. The Solicitor General's Office meets regularly with litigants, as well as other entities that are interested in cases, but those meetings "are not publicly noted . . . because there really isn't a mechanism to do so." Tom Goldstein, Practice Before the Office of the Solicitor General: Few Secret Meetings, SCOTUSBLOG.COM (Jan. 17, 2010, 9:08 PM), http://www.scotusblog.com /2010/01/practice-before-the-office-of-the-solicitor-general-few-secret-meetings-2/; see also Patricia A. Millett, "We're Your Government and We're Here To Help”: Obtaining Amicus Support From the Federal Government in Supreme Court Cases, 10 J. ApP. PrAC. \& Process 209, 215-22 (2009).

329. See generally Cass R. Sunstein, Commentary, The Office of Information and Regulatory Affairs: Myths and Realities, 126 HARV. L. REV. 1838 (2013).

330. See Lisa Heinzerling, Inside EPA: A Former Insider's Reflections on the Relationship Between the Obama EPA and the Obama White House, 31 PACE ENVTL. L. 
functions as, "in large part, an information aggregator," collecting input on proposed regulations from "a wide range of sources both inside and outside the federal government." ${ }^{\text {"311 }}$ It also meets with members of the public and works to ensure that the public-comment process functions properly so that the voices of state and local governments, businesses, and public-interest groups are heard. ${ }^{332}$ And OIRA promotes public transparency by posting some information about regulatory proposals on the internet. ${ }^{33}$ Thus, OIRA arguably fosters deliberation. ${ }^{334}$

The content of OIRA's deliberation, however, may not be publicly disclosed, ${ }^{335}$ and OIRA plays a passive role: it does not "affirm positions, volunteer information, or answer questions." 336 In addition, OIRA's review process "diffuses power to such an extent" between OIRA itself, other White House offices, and other agencies, "that at the end of the day, no one is accountable for the results it demands." ${ }^{337}$ The quality of its deliberation in a civic republican sense is thus questionable. ${ }^{338}$

REV. 325, 327-41 (2014).

331. Sunstein, supra note 329, at 1840; see also Jennifer Nou, Agency Self-Insulation Under Presidential Review, 126 HARV. L. REV. 1755, 1811-12 (2013). But see Heinzerling, supra note 330, at 345-46 (finding it "hard to make sense of Sunstein's portrait of OIRA").

332. Sunstein, supra note 329, at 1841, 1859-60.

333. See OFF. InFo. \& REG. AFF., www.reginfo.gov.

334. See Nou, supra note 331, at 1812; Kathryn A. Watts, Proposing a Place for Politics in Arbitrary and Capricious Review, 119 YALE L.J. 2, 62 (2009) ("Given that prompt letters communicate the views of the executive branch to agencies in a transparent manner that permits public scrutiny and debate, prompt letters further accountable and transparent decisionmaking.").

335. See Heinzerling, supra note 330, at 353-55; McGarity, supra note 291, at 1735-37 (describing the lack of transparency in the OIRA review process); Nou, supra note 331, at 1823-24 ("Despite provisions under current executive orders for agencies and OIRA to disclose the changes made as a result of the presidential review process, such disclosures are not regularly made in practice ...."); Dan Farber, Confessions of a Regulatory Czar, LEGAL Planet (Feb. 20, 2013), http://legalplanet.wordpress.com/2013/02/20/19886/ ("[D]ecision-making may be hidden in a fog of informal interactions within not only the White House but the entire executive branch ....").

336. Sunstein, supra note 329 , at 1860.

337. Heinzerling, supra note 330, at 326; Farber, supra note 335 (opining that OIRA review "dilutes the views of the actors with the most specific expertise" and "reduces responsibility and accountability within the executive branch"); Heinzerling, supra note 330, at 342 ("[I]t was often hard to tell who exactly was in charge of making the ultimate decision on an important regulatory matter."); $i d$. at 346 ("[A] free-for-all of regulatory power has emerged, with no one clearly in charge.").

338. See Eskridge \& Ferejohn, Republic, supra note 9, at 15 (explaining that in "republican deliberation" participants must contribute to the conversation according to "their comparative advantages," be open to different viewpoints, and "answer for the choices they make"); see also Heinzerling, supra note 330, at 364-65 (observing that opacity in government "prevents people from understanding the way their government operates, how they can intervene and at what points, what the government is up to, who is making important decisions, [and] why the government has made those decisions"); McGarity, supra note 291, at 1755-56 (noting that "[t]ransparency enhances the legitimacy of the rulemaking process ... and generally enhances the quality of the policy decisions that underlie the resulting rules"). OIRA's dubious deliberative process may contribute to what scholars claim is "a profound 
Moreover, there is no indication that OIRA's deliberation focuses regularly on the meaning of the APA. The governing executive order defines OIRA's role relative to particular "regulatory actions," not to the regulatory process generally. ${ }^{339}$ Even where OIRA "engages lawyers throughout the executive branch to help resolve ... questions of administrative procedure," 340 that inquiry necessarily will come in the context of a particular rule making. For example, if OIRA inquires whether a proposed guidance document or interpretive rule requires notice-and-comment rule making under section 553 of the APA, ${ }^{341}$ it may foster deliberation about the meaning of section 553, but only with regard to that particular guidance document or interpretive rule. ${ }^{342}$ OIRA's deliberation, therefore, does not legitimize evolutive interpretation of the APA.

\section{The Administrative Conference of the United States (ACUS)}

Finally, ACUS engages the public in deliberation about the meaning of the APA but falls short of superstatute theory's demands nonetheless. The Conference is composed of a presidentially appointed chair, a representative of each federal agency, and other individuals appointed by the President or the conference chair. ${ }^{343}$ Congress charged ACUS with studying and making recommendations concerning federal administrative procedure, as well as collecting and enabling the exchange of information that might improve administrative procedure. ${ }^{344}$ Over the years, ACUS has produced important studies and recommendations, some of which contributed to

institutional bias against regulation.” Nicholas Bagley \& Richard L. Revesz, Centralized Oversight of the Regulatory State, 106 ColuM. L. REV. 1260, 1262 (2006); see also David M. Driesen, Is Cost-Benefit Analysis Neutral?, 77 U. Colo. L. REV. 335, 378-80 (2006) (stating that OIRA acts as an antiregulatory "one-way ratchet"); Editorial, Stuck in Purgatory, N.Y. TIMES, July 1, 2013, at A22 (calling OIRA “one of the most formidable obstacles to reform").

339. See Exec. Order No. 12,866, 3 C.F.R. 638 (1994); id. at 641 (defining "regulatory action" as "any substantive action by an agency ... that promulgates or is expected to lead to the promulgation of a final rule or regulation"). Executive Order 12,866 also appointed the OIRA Administrator as the convener of a Regulatory Working Group that would analyze "important regulatory issues." Id. at 643 . That Group "worked reasonably well during the mid and late 90's as a collegial venue where regulatory policy officers could share best practices and vent shared frustrations." Sally Katzen, OIRA at Thirty: Reflections and Recommendations, 63 ADMIN. L. REV. 103, 105 (2011). However, the Regulatory Working Group is no longer functioning. Jeffrey S. Lubbers, Achieving Policymaking Consensus: The (Unfortunate) Waning of Negotiated Rulemaking, 49 S. TEX. L. REV. 987, 997 (2008); Nou, supra note 331, at 1816.

340. Sunstein, supra note 329, at 1842; see also id. at 1842 n.18 (stating "OIRA does not have the lead on legal issues"); id at 1872 (explaining that when legal issues arise, "OIRA's role will involve convening, not deciding").

341. See id. at 1853-54.

342. It is not surprising, then, that the vast majority of OIRA's meetings with people outside the government are with those who are subject to regulation. See Bagley \& Revesz, supra note 338, at 1306-07; McGarity, supra note 291, at 1746; Sunstein, supra note 329, at 1861.

343. 5 U.S.C. $\S 593(2012)$.

344. 5 U.S.C. $\S 594(2012)$. 
the 1976 amendment of the APA. ${ }^{345}$ Additionally, ACUS makes its process open to the public. ${ }^{346}$ Thus, it may provide the best opportunity for the public to provide feedback about the APA's interpretation.

Like its predecessors, ${ }^{347}$ however, ACUS does not have general rule-making authority under the APA. It may adopt regulations for carrying out its own functions, ${ }^{348}$ but Congress did not delegate to ACUS the authority to issue binding interpretations of the APA. Therefore, Congress has no reason "to expect a dynamic application of the statute" to emerge from ACUS. ${ }^{349}$ ACUS may recommend that the APA be interpreted broadly and evolutively, but absent a delegation of interpretive authority from Congress, superstatute theory would consider its efforts to exceed the enacting Congress's expectations illegitimate. ${ }^{350}$

In sum, although the APA bears the hallmarks of an entrenched superstatute, it does not undergo the sort of deliberation that superstatute theory demands to justify evolutive interpretation. Indeed, as explained in the next Part, superstatute theory supports stricter adherence to the text of the APA and allegiance to the compromises encoded in that text.

\section{Deliberation-Focused Review of the APA}

Eskridge and Ferejohn did not discuss federal superstatutes like the APA that are not subject to a deliberative feedback loop involving an administering agency, Congress, the President, the public, and the courts. I apply their theory to this new category of superstatutes. It is counterintuitive to think of Eskridge and Ferejohn as cautioning that one hesitate before stretching the text of a superstatute, but in the case of the APA, that is the result their theory yields.

345. See Richard H. Seamon, Separation of Powers and the Separate Treatment of Contract Claims Against the Federal Government for Specific Performance, 43 VILL. L. REV. 155, 183-85 (1998); see also Paul R. Verkuil, What the Return of the Administrative Conference of the United States Means for Administrative Law, 1 MicH. J. ENVTL. \& ADMIN. L. 17, 21-25, 30-31 (2012) (describing how ACUS works and listing ACUS studies related to environmental law).

346. See Admin. Conference of the United States, Public Meeting Policies and PROCEDURES (2013), available at http://acus.gov/sites/default/files/documents/Public \%20Meeting\%20Policies\%20and\%20Procedures\%20FINAL.pdf; ADMIN. CONFERENCE OF THE United States, Public COMment Policy, available at http://acus.gov/sites/default/files /documents/Public\%20Comment\%20Policy.pdf.

347. For a brief history of ACUS and its predecessors, see Jeffrey S. Lubbers, ACUS 2.0 and its Historical Antecedents, 36 ADMIN. \& REG. L. NEWs 9 (2011).

348. 5 U.S.C. $\S 595(\mathrm{a})(2)$ (2012).

349. See EsKridge \& FEREJohn, Republic, supra note 9, at 160.

350. See supra text accompanying notes 276, 283; $c f$. United States v. Mead Corp., 533 U.S. 218, 230 (2001) (holding that agency statutory interpretations receive Chevron deference only when the agency's interpretation has the force of law and that "Congress contemplates administrative action with the effect of law when it provides for a relatively formal administrative procedure tending to foster the fairness and deliberation that should underlie a pronouncement of such force," such as rulemaking or adjudication). 


\section{Deliberation-Respecting, -Inducing, and -Rewarding Review}

Because the Constitution itself is so hard to amend, the evolution of large " $\mathrm{C}$ " Constitutional law is left to "the potentially countermajoritarian and out-of-touch discretion of unelected judges." ${ }^{351}$ Eskridge and Ferejohn believe the Supreme Court has steered between "the Scylla of Constitutional ossification and the Charybdis of Court tyranny" using small "c" constitutionalism, that is, statutory evolution. ${ }^{352}$ For the law to evolve through small "c" constitutionalism without undermining democracy, however, Eskridge and Ferejohn posit that courts should be "deliberation-respecting," "353 "deliberation-inducing,"354 and "deliberationrewarding." 355

Courts should be "deliberation-respecting" insofar as they should consider deliberative materials like a statute's legislative and administrative history, recognize the "significant normative force" of deliberative processes, and defer to laws and policies "that reflect the deliberated views of Congress and the president." Supreme Court "ought to give the benefit of every Constitutional doubt" to superstatutes because they arise from "intense public debate and congressional deliberation." 357

Where the Court believes that Congress, the President, or an agency is skirting the constitutional edge or "push[ing] superstatutory evolution into significant collision with other fundamental norms," Eskridge and Ferejohn suggest that judicial review should be "deliberation-inducing," that is, it should invite further deliberation. ${ }^{358}$ Similarly, when the political system has been unresponsive or has broken down, the Court should "reverse the burden of inertia" in Congress ${ }^{359}$ and "jump-start the political process by forcing a fundamental normative discussion." "360 In essence, courts should "treat[] the legislative process like a lower court and impose[] fact finding and other requirements," ${ }^{361}$ because "important shifts of a constitutional magnitude ought not to be made without deliberation that is open and public; reasoned and factual; and legitimate." ${ }^{362}$ Courts may trigger further civic deliberation by effectively remanding cases to the political branches using, for example, the canon of constitutional avoidance or void-for-vagueness doctrine. ${ }^{363}$

351. ESKRIDGE \& FEREJOHN, REPUBLIC, supra note 9, at 434-35.

352. Id.

353. Id. at 22-23 (emphasis in original).

354. Id. at 24 (emphasis in original).

355. Id. at 24 (emphasis in original); see also id. at 435-37; Eskridge \& Ferejohn, Constitutional Horticulture, supra note 2.

356. ESKRIDGE \& FEREJOHN, REPUBLIC, supra note 9, at 266, 296, 435-36.

357. Id. at 435 .

358. Id. at 289, 436 (emphasis omitted).

359. Id. at 24 .

360. Id. at 56; see also id. at 288-89, 456. Eskridge and Ferejohn view Brown v. Board of Education, 347 U.S. 483 (1954), as an example of deliberation-inducing judicial review. Id. at 456.

361. Id. at 435 .

362. Id. at 289.

363. See id. at 464. Thus, in Heller v. District of Columbia, Eskridge and Ferejohn argue that the Court ought to have invoked the avoidance canon and interpreted federal law to preempt the District's gun regulation, thus invalidating the regulation, but not ending the public debate. Id. 
Finally, judicial review should be "deliberation-rewarding"364 or "deliberation-encouraging," that result from an effective deliberative process. ${ }^{366}$ When courts interpret superstatutes they "should be particularly attentive to agency interpretations and the reasons given by an agency" for its interpretation. ${ }^{367}$ That deference is due not because agencies are expert or because they are accountable to the people through the President, but because their statutory interpretations result from a deliberative, interactive public process: provision of public notice, receipt and serious consideration of public comments, and publication of an explanation for the agency's decision, followed by judicial review and congressional reaffirmation of the agency's initiative. ${ }^{368}$

\section{Interpreting the APA}

For a typical superstatute, Eskridge and Ferejohn advocate interpretations that stretch the text, even beyond Congress's intent. For the APA, such evolutive interpretation is unjustified. Because there is no single agency charged with implementing the APA, Congress is the locus of all deliberation about the Act that involves the public enough to be legitimate. Thus, deliberation-respecting, -inducing, and -rewarding review focuses the courts' attention on Congress. Courts should remain within the boundaries of the APA's text. To fully understand that text, however, courts must understand the Act's history and context, both pre- and post-enactment.

Deliberation-respecting review of the APA requires the courts to give effect to the compromises encoded in the Act. ${ }^{369}$ Respecting legislative compromise is critical to interpreting the APA because the Act itself was a monumental compromise. ${ }^{370}$ As the Supreme Court recognized in Wong Yang Sung v. McGrath, "The Act . . . represents a long period of study and strife; it settles long-continued and hard-fought contentions, and enacts a formula upon which opposing social and political forces have come to rest. It contains many compromises and generalities and, no doubt, some ambiguities." ${ }^{371}$

364. Id. at 24 (emphasis omitted).

365. Id. at 279 (emphasis omitted).

366. See id.

367. Eskridge, America's Statutory “constitution," supra note 9, at 36.

368. See ESKRIDGe \& FEREJohn, Republic, supra note 9, at 161, 265 ("[J]udicial review of agency interpretations of law ought to be especially deferential when the agency has engaged in model deliberation . . .."); see also id. at 277-79; Eskridge, America's Statutory "constitution," supra note 9, at 37 ("I would insist that the democratic accountability reason for deference be considered more from the bottom up (American people interacting with the agency) rather than just the top down (President directing the agency to act).").

369. See Bagley, supra note 48, at 1309; Eskridge \& Ferejohn, Super-Statutes, supra note 9, at 1247; Strauss, supra note 62, at 768-69, 781, 785.

370. See Kovacs, A History, supra note 39, at 705-06.

371. 339 U.S. 33, 40-41 (1950). The Court went on to say that it should give effect to the APA's "remedial purposes," $i d$. at 41 , essentially calling for a purposive approach the Act's interpretation. Nonetheless, the Court grappled with the text and legislative history, and ultimately based its decision on constitutional avoidance doctrine, not legislative purpose. See id. at 48-51. 
The notion that lawmaking inevitably requires legislators to compromise is the foundation of what John Manning calls "second-generation textualism." 372 Legislative compromises may result in a statute whose means "do not fully effectuate the ends that inspired" the law. ${ }^{373}$ Thus, courts that focus on a statute's purposes instead of its "implemental detail" risk undermining complex legislative bargains. ${ }^{374}$ To respect legislative compromise, second-generation textualists pay close attention to statutory text.

Eskridge agrees that courts must respect compromises encoded in legislation, but he disagrees with Manning about what an interpreter examines to understand a legislative compromise. Where Manning would have courts focus on the enacted text, Eskridge would have courts consider in addition "the context of the statute, ... the explanation of the deal in the committee reports, and the statute's purpose," as well as evidence of interest groups' views. ${ }^{375}$ Indeed, as Victoria Nourse points out, it may be necessary to examine legislative history simply to identify which statutory provisions are compromises. ${ }^{376}$ Eskridge and Nourse have the stronger position in this debate. Some provisions of the APA represent "wins" for the conservative minority, others reflect the success of the liberal majority to dilute conservative proposals, and many were compromises. ${ }^{377}$ The text alone does not reveal which is which. Hence, to give sufficient weight to the bargain Congress and the President made in 1946, the courts must understand the APA's full context and history. ${ }^{378}$

Deliberation-respecting review also requires the courts to examine ongoing deliberation on particular provisions of the APA. ${ }^{379}$ Peter Strauss contends that the Supreme Court failed to do that when it invalidated a Department of Labor burden-shifting rule in Director, Office of Workers' Compensation Programs v.

372. John F. Manning, Second-Generation Textualism, 98 CALIF. L. REV. 1287, 1290 (2010).This article appears in an issue honoring Philip Frickey, William Eskridge's frequent coauthor. Editor's Note, 98 CALIF. L. REV. ii (2010).

373. Manning, supra note 372 , at 1304.

374. Id.; see also id. at 1290, 1310-11.

375. William N. Eskridge, Jr., No Frills Textualism, 119 HARV. L. ReV. 2041, 2053 (2006) (reviewing Adrian Vermeule, Judging Under UnCERTAinty (2006)); see also William N. Eskridge, Jr., The New Textualism, 37 UCLA L. Rev. 621, 633-34 \& n.48 (1990).

376. Victoria F. Nourse, A Decision Theory of Statutory Interpretation: Legislative History by the Rules, 122 YALE L.J. 70, 119 (2012) (arguing that one cannot identify compromises in legislation "without looking at the legislative history and the rules governing it"); see also Bressman \& Gluck, Part II, supra note 42, at 741-43 (pointing out that some kinds of legislative history reflect legislative intent more accurately than statutory text); Gluck \& Bressman, Part I, supra note 42, at 911 (calling for "a more nuanced account of how statutes are produced in the modern regulatory state"); Nourse, supra, at 138 n.296.

377. See generally Shepherd, supra note 3.

378. Cf. Gluck \& Bressman, Part I, supra note 42, at 965 (reporting that in empirical study of congressional staffers, "legislative history was emphatically viewed by almost all . . . respondents - Republicans and Democrats, majority and minority-as the most important drafting and interpretive tool apart from text" (emphasis in original)); see also id. at 967-90 (examining role of legislative history in statutory drafting process and concluding that "the real question about legislative history is not whether it should be consulted but, rather, how to separate the useful from the misleading").

379. Cf. ESKRIDGE \& FEREJOHN, REPUBLIC, supra note 9, at 297-98. 
Greenwich Collieries. ${ }^{380}$ The APA provides that "the proponent of a rule or order has the burden of proof." "381 For decades, the agency had imposed on benefits claimants only the burden of production. ${ }^{382}$ The Court invalidated the agency's approach, holding that the APA requires claimants to carry the burden of persuasion. ${ }^{383}$ Strauss argues that, in reaching that result, the Court ignored post-1946 legislation, regulations interpreting other statutes, and court decisions. ${ }^{384}$ If Strauss is correct, the Greenwich Collieries Court did not show sufficient respect for ongoing deliberation to legitimize its ruling. ${ }^{385}$

Of course, ongoing deliberation may render administrative common law that once contradicted Congress's intent innocuous. Just as the 1982 amendments to the Endangered Species Act endorsed the Interior Department's broad interpretation of "harm," 386 so too might an amendment of the APA endorse a court's broad interpretation of the APA. Mere congressional silence is not likely to reflect sufficient deliberation to legitimize administrative common law that contradicts the enacting Congress's intent. ${ }^{387}$ Chevron, however, may be an exception.

380. See Strauss, supra note 245, at 1413-19 (discussing Dir., Office of Workers' Comp. Programs, Dep't of Labor v. Greenwich Collieries, 512 U.S. 267 (1994)).

381. 5 U.S.C. $\S 556(d)$ (2012).

382. See Strauss, supra note 245 , at $1417-19$.

383. Greenwich Collieries, 512 U.S. at 276.

384. Strauss, supra note 245, at 1418-20; Peter L. Strauss, On Resegregating the Worlds of Statute and Common Law, 1994 SuP. CT. ReV. 429, 487-88 [hereinafter Strauss, On Resegregating]. Strauss argues that the APA should not be limited to its ordinary meaning in 1946, but rather is "an evolving statute," though its "evolution, to be sure, [is] limited by the possibilities of its text." Strauss, supra note 245, at 1420.

385. For a typical superstatute, deliberation-respecting review would also entail considering the statute's administrative history, that is, how the agency has implemented the statute. ESKRIDGE \& FEREJOHN, REPUBLIC, supra note 9, at 266. Since the APA is not administered by any particular agency, however, such agency-based deliberation is absent. For the same reason, judicial interpretations of the APA cannot be deliberation-rewarding because there is no agency interpretation of the APA that is entitled to deference. See text accompanying notes 319-320.

386. ESKRIDGE \& FEREJOHN, REPUBLIC, supra note 9, at 274, 297.

387. See Bagley, supra note 48, at 1328-29 (arguing that Congress has not acquiesced in the presumption of reviewability); Amy Coney Barrett, Statutory Stare Decisis in the Courts of Appeals, 73 GEO. WASH. L. REV. 317 (2005) (arguing that congressional acquiescence does not support statutory stare decisis in the federal courts of appeals); William N. Eskridge, Jr., Overruling Statutory Precedents, 76 GEO. L.J. 1361 (1988) (arguing that legislative acquiescence does not justify the "super-strong presumption against overruling statutory precedents," $i d$. at 1363, because "[i]n most instances, Congress is either not aware of the Court's statutory interpretations or faces no formal opportunity to examine those interpretations," $i d$. at 1404, and "[e]ven when those interpretations are brought to the attention of a congressional committee, the rest of Congress usually remains unaware of them," id.). But see Matthew R. Christiansen \& William N. Eskridge, Jr., Congressional Overrides of Supreme Court Statutory Interpretation Decisions, 1967-2011, 92 TEX. L. REV. 1317, 1461 (2014) ("When the Court has interpreted a statute and Congress has engaged in an open, deliberative, and pluralistic appraisal of the Court's decision without overriding it, that ought to be an additional reason for the Court to be reluctant to overrule its statutory precedent."). 
Congressional staffers are clearly aware of Chevron's deference doctrine, ${ }^{388}$ and in each new statute providing rule-making authority, Congress may provide that Chevron does not apply. ${ }^{389}$ Moreover, Chevron survived efforts to reverse it in the Bumpers Amendment, which was the subject of significant deliberation. ${ }^{390}$

The courts' interpretation of the APA also should seek to induce further deliberation in Congress. Superstatute theory would not accept judicial deliberation as a "second best" alternative but instead would prefer that courts respect, induce, and reward a civic-republican style of deliberation. ${ }^{391}$ If the boundaries of the APA's possible meaning need to be extended, the courts should prod Congress to extend them. ${ }^{392}$ Indeed, that appears to be the preference of those who draft federal statutes. The respondents in Gluck and Bressman's groundbreaking empirical study of congressional drafting practices reported that "they would rather have difficult questions returned to Congress than resolved by judges." ${ }^{393}$ Perhaps the Court in Greenwich Collieries adhered to the APA's meaning in 1946 in an effort to encourage Congress to update the statute to "capture[] the new social and political realities."394

388. See Gluck \& Bressman, Part I, supra note 42, at 927, 993-98.

389. See, e.g., Dodd-Frank Wall Street Reform and Consumer Protection Act $\S 1044(\mathrm{a})$, 12 U.S.C. $\S 25 b(b)(5)(A)$ (2012) (providing that certain rules of the Office of the Comptroller of the Currency be reviewed, consistent with Skidmore, based on "the thoroughness evident in the consideration of the agency, the validity of the reasoning of the agency, the consistency with other valid determinations made by the agency, and other factors which the court finds persuasive and relevant to its decision"). Thanks to Asher Steinberg for this point.

390. See Levin, Review, supra note 253, at 358-66; O'Reilly, supra note 253, at 747-67. "The so-called Bumpers Amendment went through several iterations and in its mature form provided that courts should 'independently decide all relevant questions of law' and that 'in making determinations on ... questions of law, the court shall not accord any presumption in favor of or against agency action." William R. Andersen, Against Chevron-A Modest Proposal, 56 ADMIN. L. REV. 957, 974 (2004).

391. See supra Part IV.C.1; see also Lawrence Solum, Legal Theory Lexicon: Second Best \& Nonideal Theory, LEgAL THEORY BLOG (Sept. 14, 2014), http://lsolum.typepad.com /legaltheory/2014/09/legal-theory-lexicon-second-best-nonideal-theory.html ("[W]hen the first-best policy option is unavailable, then normative legal theorists should consider second-best solutions.").

392. Cf. Einer Elhauge, Preference-Eliciting Statutory Default Rules, 102 CoLUM. L. REV. 2162, 2165, 2967 (2002) (arguing that canons of statutory interpretation serve preference-eliciting functions designed "to provoke a legislative reaction that resolves the statutory indeterminacy and thus creates an ultimate statutory result that reflects enactable political preferences more accurately than any judicial estimate possibly could"); Cass R. Sunstein, Nondelegation Canons, 67 U. CHI. L. REV. 315, 317, 335 (2000) (arguing that certain "nondelegation canons" of statutory interpretation, like the canon disfavoring extraterritorial application of federal law and the canon disfavoring interpretations that raise serious constitutional doubts, "represent a salutary kind of democracy-forcing minimalism, designed to ensure that certain choices are made by an institution with a superior democratic pedigree").

393. Gluck \& Bressman, Part I, supra note 42, at 1015; see also Bressman \& Gluck, Part II, supra note 42 , at $773-74$.

394. Strauss, supra note 245, at 1421. Congress has not overruled Greenwich Collieries. Dir., Office of Workers' Comp. Programs, Dep't of Labor v. Greenwich Collieries, 512 U.S. 267 (1994). 
The bottom line is that identifying a statute as a superstatute does not necessarily justify interpreting that statute broadly, much less exceeding Congress's intentions. One cannot simply dub the APA a superstatute and announce that it must therefore be interpreted to evolve beyond the boundaries of the text. Rather, given the extraordinary legislative process that led to the APA's enactment and the relative paucity of agency-based deliberative feedback since then, courts should be particularly cautious about interpreting the APA's text in a way that shifts the balance Congress reached through the political process. Courts should look closely at the APA's individual provisions, including Congress's treatment of each provision in the original legislative process and the quality of deliberation the provision has seen since enactment. ${ }^{395}$

\section{Administrative Common Law's Weakness}

Just as Kryptonite weakens Superman, ${ }^{396}$ superstatute theory weakens administrative common law. The flaw superstatute theory reveals in administrative common law is not simply its derivation in countermajoritarian courts. ${ }^{397}$ Rather, the problem is that the courts are not engaged in a deliberative feedback loop with an agency that in turn parleys with the public and (unlike the other branches of government) has an obligation to respond to the public's views. ${ }^{398}$ This deliberation deficiency makes it problematic to stretch the APA's text too far, much less impose doctrines of administrative common law that extend the law beyond the text's breaking point and conflict with Congress's intent. ${ }^{399}$

As mentioned in Part I, although scholars have endorsed administrative common law since the APA was enacted, Gillian Metzger has written its most comprehensive and convincing defense. ${ }^{400}$ Metzger believes that little can be gained by resisting administrative common law and that any debate about administrative common law devolves to an inquiry about "whether a particular instance of judicial lawmaking falls within the acceptable range." 401 To enable that inquiry, Metzger prescribes increased judicial candor. ${ }^{402}$

395. Interpretation of the APA should be tailored to the unique circumstances of this particular enactment. Cf. Bressman \& Gluck, Part II, supra note 42, at 797-800 (arguing that the Court tailors statutory interpretation doctrine to different circumstances).

396. DC Comics v. Kryptonite Corp., 336 F. Supp. 2d 324, 327 (S.D.N.Y. 2004) ("Superman's sole weakness is his vulnerability to several forms of Kryptonite, an element from Superman's home planet."); $c f$. Sam Deloria, Commentary on Nation-Building: The Future of Indian Nations, 34 ARIZ. ST. L.J. 55, 55 (2002) ("The saddest thing of all is the number of Indian academics who basically yearn for a time which never existed, when Indian sovereignty was like Superman in a universe without kryptonite. That never even happened for Superman. Somebody always had a little rock of kryptonite to whip out and Superman was toast.").

397. See Kovacs, Leveling, supra note 38, at 600, 604.

398. See Metzger, supra note 24 , at 530 .

399. Cf. Strauss, supra note 245, at 1420 (interpretation of the APA must be constrained "by the possibilities of [the] text”); see also Strauss, On Resegregating, supra note 384, at 440-41.

400. See supra text accompanying note 70 .

401. Metzger, supra note 16, at 1348; see also id. at 1351, 1355. This point is well taken, particularly since I have cabined my inquiry here to common law that contradicts or ignores the APA.

402. Id. at 1370; accord Kovacs, Leveling, supra note 38, at 635-38 (prescribing judicial 
In many ways, Metzger's analysis is right on target. Administrative common law may be important and unavoidable in some contexts, and the courts certainly should be more transparent in their development of administrative common law. Applying superstatute theory to the APA, however, reveals a principal weakness in administrative common law: the absence of ongoing public deliberation about the $\mathrm{APA}$ at the agency level renders administrative common law suspect and requires the courts to pay closer attention to the APA itself and to the legislative process. Even Metzger's formidable defense cannot stand up to the deliberation deficiency superstatute theory exposes in the APA.

For administrative common law to be legitimate, it must answer concerns related to not only separation of powers and political accountability but also public deliberation. The separation-of-powers objection to common law is familiar. The Constitution separates Congress's power to make laws from the courts' power to interpret laws in order to avoid tyranny and safeguard liberty. ${ }^{403}$ As Thomas Merrill concluded, "[I]nstitutionalization of lawmaking by federal courts would represent a major shift in policymaking power away from Congress and toward the federal judiciary, in violation of the constitutional scheme." ${ }^{404}$ I do not claim that all federal common law raises separation-of-powers concerns, but administrative common law that ignores or contradicts the APA certainly does.

Metzger argues that separation-of-powers concerns are not an "obstacle" to administrative common law because administrative common law "can advance separation of powers values" by structuring the relationships between the branches. ${ }^{405}$ Certainly the courts may "preserve checks and balances and avoid a single branch's aggrandizement" on some occasions, ${ }^{406}$ but that does not solve the fundamental problem of the courts believing that they have the power to decide whether and when to do so. ${ }^{407}$ Metzger claims that Congress's power to override administrative common law decisions can prevent excessive judicial aggrandizement, particularly if courts are more candid in developing administrative common law. ${ }^{408}$ Even if congressional vetogates did not hinder the passage of legislation, ${ }^{409}$ the possibility of a legislative override does not justify the courts

candor as a means of ending the common law practice of giving super deference to the military). 403. See Kovacs, Leveling, supra note 38, at 600-02; Merrill, supra note 29, at 19-20.

404. Merrill, supra note 29, at 23.

405. Metzger, supra note 16, at 1346-47; accord Bremer, supra note 16, at 1267-68 (arguing that administrative law's "unwritten constitution" imposes limits on judicial lawmaking and "provides a basis for evaluating the substantive validity of administrative common law rules"); Christopher J. Walker, The Ordinary Remand Rule and the Judicial Toolbox for Agency Dialogue, 82 GEO. WASH. L. REV. (forthcoming 2014) (manuscript at 7), available at http://papers.ssrn.com/sol3/papers.cfm?abstract_id=2242869 (arguing that administrative common law can enable the courts to "strike the right balance of powers between courts and agencies").

406. Metzger, supra note 16, at 1346.

407. Cf. Bagley, supra note 48, at 1327 ("[T] he courts have no business contorting statutes to accord with background values, however widely held courts believe those values to be.").

408. Metzger, supra note 16, at 1347, 1356; see also Metzger, supra note 24, at 511; Gluck, supra note 24 , at 807.

409. See generally Eskridge, Vetogates, supra note 292; see also Bressman, supra note 63, at 1773 (asserting that Congress's ability to overrule common law standards of review is 
invading Congress's lawmaking turf in the first place. ${ }^{410}$ Moreover, Metzger admits that a lack of judicial candor makes it difficult for the political branches to respond effectively to court decisions, ${ }^{411}$ and she doesn't explain how more judicial candor will solve that problem given that it is Congress's inability to act which she contends makes administrative common law inevitable. ${ }^{412}$

Even if traditional separation-of-powers concerns do not undermine administrative common law's legitimacy, there is the related but distinct problem of its lack of political accountability. ${ }^{413}$ Thomas Merrill explained that federal common law is constrained not just by federalism and separation of powers but also by "the principle that public policy should be made by officials who are answerable to the people through periodic elections." ${ }^{414}$ The fact that federal judges are not elected cannot bar judicial lawmaking, he posited, since the Constitution designed the federal courts that way. ${ }^{415}$ Nonetheless, "[a]ny exercise of lawmaking by federal courts represents a potential erosion of the principle of electoral accountability and hence presents a problem of legitimacy." 416

Just as administrative common law can further separation-of-powers values, Metzger argues, so too can it address the concern about political accountability "by fostering effective congressional and presidential controls on administrative action." ${ }^{\prime 17}$ That the Court may choose to enhance the political accountability of agencies in certain cases, however, does not make the Court itself politically accountable when creating administrative common law.

Metzger makes a valid point in arguing that separation-of-powers and political accountability objections to common law go too far. If those objections are sustained, then all common law is constitutionally illegitimate, and such an absolute objection to common law does not comport with current legal doctrine, which acknowledges

limited because such standards "are too amenable to case-by-case elaboration, rather than legislative consensus").

410. Merrill, supra note 29, at 22-23, 26. Abbe Gluck argues that conceptualizing statutory interpretation principles as common law "would alleviate separation of powers concerns," because Congress can revise common law by statute. Gluck, supra note 24, at 807. Administrative common law differs from statutory interpretation principles, however, insofar as Congress has already enacted legislation; the courts' persistent reliance on administrative common law does not pay adequate respect to Congress's efforts.

411. Metzger, supra note 16 , at 1356-57.

412. Metzger's contention that administrative common law gives the courts room to address constitutional concerns about the Fourth Branch "without having to confront those tensions head on," see id. at 1321, 1339-41, is out of sync with her ultimate plea for more transparency in the development of administrative common law, see id. at 1370.

413. See Jide O. Nzelibe \& Matthew C. Stephenson, Complementary Constraints: Separation of Powers, Rational Voting, and Constitutional Design, 123 HARV. L. REV. 617, 624-27 (2010).

414. Merrill, supra note 29, at 24.

415. Id. at 25 .

416. Id. at 27. Traditionally, however, elections are considered the "primary control" on government, and separation of powers is an "auxiliary precaution." Nzelibe \& Stephenson, supra note 413, at 625 (quoting THE FEDERALIST No. 51, at 290 (James Madison) (Clinton Rossiter ed., 1999)).

417. Metzger, supra note 16, at 1347. 
that courts may sometimes "create law." $" 418$ The Administrative Procedure Act is distinguishable, however, because Congress and the President put so much effort into shaping this law, both before and after its enactment. The Act's history raises the separation-of-powers stakes. Saying that the courts should respect that exceptional legislative effort is not tantamount to saying that courts should never make law. Rather, it simply urges that judicial review should be deliberation-respecting. In any event, I do not take issue with administrative common law where Congress has carved out space for it or employed terms so capacious as to invite it. ${ }^{419}$ Rather, my focus here is on administrative common law that contravenes or ignores the APA, instances when the courts have not exercised their usual caution in fashioning federal common law.

Moreover, superstatute theory reveals a third legitimacy problem with this kind of administrative common law in addition to separation of powers and political accountability: lack of public deliberation. Eskridge and Ferejohn explained that the common-law approach to constitutional law has the benefit of allowing the Constitution to be updated over time, but it is "unconnected to public feedback" and thus "runs the risk of alienating fundamental law from popular sources of legitimacy." ${ }^{, 20}$ Similarly, administrative common law provides an efficient means of updating the law, but it is virtually unmoored from public deliberation because there is no agency that has the authority to issue binding interpretations of the APA and that engages in an ongoing dialogue with both the courts and the public. ${ }^{421}$ Indeed, Metzger recognizes that administrative common law is difficult "to square with the principle of democratic government," given that it is "shielded from public acknowledgment and scrutiny." ${ }^{" 422}$ This is administrative common law's principal weakness.

Just as administrative common law may further separation-of-powers values and foster political accountability, so too may it enhance public deliberation. ${ }^{423}$ The courts developed common law governing rule-making procedures, for example, "to facilitate meaningful public participation and transparency in rulemaking." ${ }^{.424}$ But the public involvement that body of common law may facilitate typically concerns an agency's interpretation of a substantive statute, not the APA, and thus does not facilitate civic-republican deliberation about the APA or the common law doctrines themselves. Moreover, administrative common law can have unforeseen consequences. ${ }^{425}$ The

418. Id. at 1347-48. Whether current legal doctrine is flawed is beyond the scope of this Article.

419. See supra text accompanying notes 33-36.

420. ESKRIDGE \& FEREJOHN, REPUBLIC, supra note 9, at 445.

421. Cf. Seidenfeld, Civic Republican Justification, supra note 291 (arguing that agency-based deliberation has the best potential for meeting the civic republican ideal).

422. Metzger, supra note 16, at 1356; see also Metzger, supra note 105, at 1928-29 (recognizing that courts are insulated from political and popular influence); Seidenfeld, Civic Republican Justification, supra note 291, at 1543-44 (explaining why court deliberation does not meet the civic-republican ideal).

423. See Bressman, supra note 63, at 1769-70, 1776-77, 1791 (arguing that the Court develops some administrative law doctrines to enhance congressional oversight by giving constituents access to information); Emily Hammond \& David L. Markell, Administrative Proxies for Judicial Review: Building Legitimacy from the Inside-Out, 37 HARV. ENVTL. L. REV. 313, 316-17, 323, 325 (2013) (arguing that administrative law doctrines reinforce values including deliberation, participation, and transparency).

424. Kristin E. Hickman, Unpacking the Force of Law, 66 VAND. L. REV. 465, 520 (2013).

425. See Bagley, supra note 48, at 1328-36 (detailing the consequences of the common 
common law governing notice-and-comment rulemaking contributed to regulatory ossification. ${ }^{426}$ Perhaps if those common law requirements had been subject to more civic-republic deliberation, that result could have been avoided. As Nicholas Bagley said in reference to the common law presumption of reviewability, Congress struck a balance "between a host of incommensurate values. It is Congress's role, not the courts', to strike that balance. .. . The courts have no constitutional authority to revise that judgment and no epistemic basis for thinking they can make a better one." ${ }^{\prime 427}$

Metzger argues that administrative common law is inevitable because Congress cannot keep statutes up to date, much less constrain agencies effectively. That disability requires the courts to step in to keep agencies in line. ${ }^{428}$ Yet, administrative common law is not always inevitable, as evidenced by Vermont Yankee, ${ }^{429}$ Greenwich Collieries, ${ }^{430}$ Dickinson v. Zurko, ${ }^{431}$ and other cases in which the Supreme Court adhered strictly to the text of the APA. Judicial review can respect the deliberation that has occurred and instigate further deliberation. Wong Yang Sung ${ }^{432}$ is a prime example: within six months of the Supreme Court's decision that the APA applied to Immigration and Naturalization Service adjudications, Congress overturned it. ${ }^{433}$ The APA saw significant deliberation pre-enactment, and it has seen much deliberation since. ${ }^{434}$ In fact, the APA is currently the subject of heated debate in Congress. ${ }^{435}$ To respect that deliberation and encourage further deliberation, the courts should stay within the boundaries of the APA's text and prod Congress to answer the unanswered questions. ${ }^{436}$

One might object that Congress is too dysfunctional to be the focus of deliberation. The 111 th Congress, however, from January 2009 to January 2011, was the most productive in decades. ${ }^{47}$ As Matthew Christiansen and William Eskridge

law presumption of reviewability).

426. See Mark Seidenfeld, Demystifying Deossification: Rethinking Recent Proposals To Modify Judicial Review of Notice and Comment Rulemaking, 75 TEX. L. REV. 483, 483-84 (1997) ("[D]evelopments in administrative law over the past two decades that were meant to expand public participation and influence in administrative decisionmaking have unintentionally" led to "ossification.").

427. Bagley, supra note 48, at 1330; see also id. at 1322.

428. See Metzger, supra note 16, at 1322, 1329, 1331.

429. Vt. Yankee Nuclear Power Corp. v. NRDC, 435 U.S. 519 (1978).

430. Dir., Office of Workers' Comp. Programs, Dep't of Labor v. Greenwich Collieries, 512 U.S. 267 (1994).

431. 527 U.S. 150 (1999).

432. Wong Yang Sung v. McGrath, 339 U.S. 33 (1950).

433. See Marcello v. Bonds, 349 U.S. 302, 306 (1955).

434. See supra Parts III.A, C.

435. See, e.g., Regulations from the Executive in Need of Scrutiny Act of 2013, S. 15, 113th Cong. (2013).

436. Of course, Congress may debate and override administrative common law decisions, but the possibility of after-the-fact legislative deliberation does not legitimize the courts' disrespect for deliberation that came before. See Merrill, supra note 29, at 22, 26.

437. See Josh Chafetz, The Phenomenology of Gridlock, 88 Notre DAmE L. Rev. 2065, 2078, 2085 (2013); David A. Fahrenthold, Philip Rucker \& Felicia Sonmez, Stormy 111th Congress Was Still the Most Productive in Decades, WASH. Post (Dec. 23, 2010), http:/www.washingtonpost.com/wp-dyn/content/article/2010/12/22/AR2010122205620.html. 
found in their empirical study of congressional overrides of Supreme Court statutory interpretation decisions, "Congress is capable of policy responses even in periods of divided government and partisan acrimony." $" 338$ The APA itself has seen significant legislative deliberation in recent years. ${ }^{439}$ So, Congress does still deliberate. Nonetheless, even if Congress is dysfunctional, that does not justify abandoning the constitutional design and allowing courts to enable that dysfunction.

Deliberation-respecting review of the APA would be the death knell of administrative common law that contradicts or ignores the APA. For example, the same arbitrary or capricious standard of review applies to all agencies, and the history of the APA confirms that Congress intended for all agencies to be treated alike. The courts' practice of giving super deference to particular agencies, like the military, exceeds the boundaries of the text and contradicts Congress's intent, making it illegitimate. ${ }^{440}$ The same can be said of prudential ripeness doctrine, which contradicts the APA's provision of a cause of action for any person with the requisite harm who challenges "final agency action" by injecting considerations of judicial competence. ${ }^{411}$ Many of the courts' rulemaking requirements exceed the boundaries of the APA's text. ${ }^{442}$ In the pending case of Perez v. Mortgage Bankers Association, the Supreme Court should reverse the D.C. Circuit's holding that agencies must go through notice and comment before significantly revising interpretive rules because that holding directly contradicts the APA. ${ }^{443}$ Similarly, Judge Kavanaugh observed that the Portland Cement doctrine, which requires agencies to disclose the studies upon which they rely in rulemaking, "cannot be squared with the text of $\S 553$." Finally, in employing Chevron doctrine - aside from the efforts of individual justices in dissents - the Court has largely ignored the APA. It is entirely possible that the current view of Chevron can be harmonized with statutory text and history, ${ }^{445}$ but the Court must do so if it is to pay adequate respect to civic-republican deliberation.

438. Christiansen \& Eskridge, supra note 387, at 1460; see also id. at 1333, 1339. Christiansen and Eskridge predicted that, in the long term, "pressures from interest groups, agencies, and the states ought to press Congress to update aging superstatutes, with the result being a resurgence of overrides." Id. at 1353.

439. See supra text accompanying notes 252-258. Jody Freeman and David B. Spence contend that Congress is unlikely to enact regulatory legislation and thus "the normative commitment to democracy-forcing is based on a flawed empirical assumption about the probability of congressional action." Jody Freeman \& David B. Spence, Old Statutes, New Problems, 163 U. PA. L. REV. 1, 75 (2014). I am less concerned about Congress enacting legislation, however, than I am about Congress deliberating. Moreover, Freeman and Spence's response to Congress's dysfunction is to allow agencies to fill the policymaking gaps, not courts. The APA does not provide that alternative.

440. See supra text accompanying notes 39-42.

441. See supra text accompanying notes 43-47.

442. See supra text accompanying notes 59-63.

443. See Mortgage Bankers Assoc. v. Harris, 720 F.3d 966 (D.C. Cir. 2013), cert. granted, 134 S. Ct. 2820 (2014); see also 5 U.S.C. § 553(b)(A) (2012); Sunstein \& Vermeule, supra note 14 (manuscript at 24-29).

444. Am. Radio Relay League v. FCC, 524 F.3d 227, 246 (D.C. Cir. 2008) (Kavanaugh, J., concurring in part and dissenting in part) (discussing Portland Cement Ass'n v. Ruckelshaus, 486 F.2d 375, 392-93 (D.C. Cir. 1973)).

445. See supra text accompanying notes 54-57. 
In the end, Metzger may not disagree with my contention that these and other doctrines of administrative common law should fall. She points out that "[s]ome judicial moves may be deemed unsupportable because they simply conflict too much with governing statutes. ${ }^{" 46}$ But Metzger starts from the position that administrative common law is important, inevitable, and legitimate. ${ }^{447}$ I start from the opposite position - that administrative common law is suspect. Courts should respect the civic-republican deliberation reflected in the APA's text and in the pre- and post-enactment legislative history and avoid shifting the balance Congress reached through the political process.

\section{CONCLUSION}

Eskridge and Ferejohn's theory of superstatutes makes an important contribution to the law. Among many other things, it provides a lens through which we may examine particular statutes. Viewing the APA through that lens reveals unexpected results. Instead of supporting broad, evolutive interpretations of the APA, superstatute theory advises closer adherence to the statute's text and Congress's expectations.

The APA is a quasi-constitutional, entrenched superstatute. Unlike a typical superstatute, however, the APA is not administered by a single agency. Hence, the APA is not subject to the sort of administrative deliberation upon which superstatute theory depends to justify interpreting superstatutes evolutively. The public is not included in any feedback loop with an agency, Congress, the President, and the courts engaged in interpreting the APA.

Eskridge and Ferejohn did not discuss statutes like the APA that bear the hallmarks of a superstatute but are not subject to an administrative feedback loop. Nonetheless, their work points in a particular direction, albeit not the direction one might anticipate. Rather than supporting evolutive interpretations of the APA, superstatute theory's focus on deliberation counsels hesitation before stretching the terms of the statute. In the absence of an administering agency, Congress is the locus of public deliberation about the APA. Thus, deliberation-focused review of the APA centers on the deliberation in the legislative process before and after 1946 and requires close attention to the compromises encoded in the Act. If that inquiry does not answer a question that requires an answer, the courts should prod Congress to deliberate further and provide an answer.

Administrative common law contradicts that deliberation-focused approach. In other areas of the law, an agency links judicial consideration to the public, the President, and Congress. But when courts impose rules of administrative law that stretch the APA's text beyond its breaking point, those rules are unmoored from any public deliberation and therefore cannot be considered legitimate.

446. Metzger, supra note 16, at 1353.

447. Id. at 1296-97. 